\title{
Crosstalk in Tri-positive Cancer: Predictor and Diagnostic Mirnas in Focus
}

\author{
Jude Ogechukwu Okoye ${ }^{1, *}$, Anthony Ajuluchukwu Ngokere ${ }^{2}$ \\ ${ }^{1}$ Histopathology Unit, Department of Medical Laboratory Science, School of Public and Allied Health, Babcock University, Nigeria \\ ${ }^{2}$ Histopathology Unit, Department of Medical Laboratory Science, Faculty of Health Sciences, Nnamdi Azikiwe University, Nigeria
}

Copyright $(2016$ by authors, all rights reserved. Authors agree that this article remains permanently open access under the terms of the Creative Commons Attribution License 4.0 International License

\begin{abstract}
Cancer is a complex multifaceted disease caused by alterations at the genetic or epigenetic level in cells. Cancers in females majorly consist of ovarian, breast and cervical cancers, all of which, occurring concurrently, are referred to as 'Tri-positive cancer (TPC)'. Genetic and epigenetic mechanisms in TPC involve microRNAs; which are a class of endogenous, small, non-coding RNAs of 22 to 24 nucleotides that control gene expression. In TPC, upregulated oncogenic miRNAs includes: miR-21, miR-146a, miR-155, miR-182 and miR-200c while the downregulated tumour suppressor miRNAs includes: let-7b, miR-125b, miR-143 and miR-145. Cross-talk in TPC, which is the interaction between miRNAs and pathways, is an upshot of a complex network engaging the interplay of target genes such as PTEN, Muc-1, ERRB2/3, ZEB1/2, RAS, Bcl-2 and c-Myc among others, and occurring mostly through the P13k/Akt signaling pathway. Furthermore, an inverse relationship between miR-146a and miR-182, and BRCA gene with a direct relationship between miR-125b and BRCA gene was observed in the emergence of TPC. This review also showed that there are variations in the expression of let-7, miR-21, miR-125b and miR-200c between Tumour Initiating Cells (T-ICs) and TPC. Thus, since some of these miRNAs are dysregulated in chronic inflammations which play a critical role in tumourigenesis, proper investigation of these miRNAs and target genes in high risk individuals may aid prediction and early diagnosis of cancer and effective therapy with high reduction in mortality.
\end{abstract}

Keywords Ovarian Cancer, Breast Cancer, Cervical Cancer, Mirna Expression, Crosstalk, BRCA Gene

\section{Introduction}

Tri-positive cancer (TPC) refers to the simultaneous occurrence of ovarian, breast and cervical cancers in the female reproductive tract of an individual. Cancer is a complex multifaceted disease caused by alterations in tumor suppressor and oncogenes either at the genetic or epigenetic level [1]. Epigenetic alterations include DNA methylation, histone modifications, and small noncoding RNA molecules, including miRNAs [2]. MicroRNAs are a class of endogenous, small, non-coding RNAs (22-24 nucleotides in length) that control gene expression by interacting with target mRNAs [3]. Tumor formation may arise from downregulation of a tumor suppressor miRNA or upregulation of an oncogenic miRNA [4]. Upregulation of tumorigenic miRNAs in human cancers can result from amplification, deregulation of a transcription factor, or demethylation of $\mathrm{CpG}$ islands in the promoter regions of the corresponding genes. Tumor suppressor miRNAs can be downregulated in cancer through several pathways or mechanisms which include deletions, epigenetic silencing, or loss of transcription factor expression [5] among others.

The interaction between miRNAs, genes and pathways is referred to as cross-talk [2]. An alteration of this cross-talk in cells may result in cancer. Dysregulation of 5 oncogenic miRNAs (miR-21, miR-146a, miR-155, miR-182 and miR-200c) and 4 tumour suppressor miRNAs (Let-7b, miR-125b, miR-143 and miR-145) have been implicated in TPC. However, reports of miR-214 expression in TPC appear to be controversial. Reports have shown that a BRCA1 or BRCA2 mutation in women increases the risk of Tri-positive cancer by 3 fold [6-9]. Despite the fact that several studies have suggested that BRCA and miRNAs play crucial roles in cell activities, the pathways through which BRCA mutation and miRNA dysregulation result in TPC is yet to be fully elucidated. This review paper aimed to evaluate the connection between BRCA mutation and miRNA cross-talk in the manifestation of Tri-positive cancers.

\section{Tumour Suppressor miRNAs}

Underexpression of tumour suppressor miRNAs such as let-7b, miR-125b, miR-143 and miR-145 has been reported in TPC (Table 1). Despite the fact that the expression of 
miR-214 in TPC is controversial in literature, its regulation in different cancers is discussion worthy.

\subsection{Repression of Let-7b in Neoplastic Diseases}

Let-7b, a tumour suppressor, is one of the twelve variants of the let-7 family reported in literature. It is overexpressed during embryonic cell differentiation [10] and underexpressed in various cancers. It regulates apoptosis and cancer stem cell differentiation when compared with normal tissues [11-14]. However, overexpression of let-7b has been reported in some cancers which suggest that let- $7 \mathrm{~b}$ does not play a tumor suppressor role in all cases. Such phenomenon is observed in a case of malignant mesothelioma, where let-7b was overexpressed [15]. The underexpression of let-7b offers cancer stem cells unlimited self-renewal and metastatic capabilities [16,17]. During tumorigenesis, the let-7b targets embryonic genes (regulons) which are unexpressed in adult tissues promote de-differentiation and cancer progression [18]. An example of such regulons is HMGA2. The target, HMGA2, is a direct target of let-7b [19] and also a chromatin associated nonhistone protein which controls chromatin architecture.

Let-7b alterations in tumours are adduced to chromosomal aberrations on 12q13-15. It is untraceable in most differentiated tissues, but overexpressed in many cancers such as neuroblastoma, pancreatic, lung and thyroid cancers, and hematopoietic and fetal neuronal stem cells [20-26]. Overexpression of HMGA2 and underexpression of let-7b have strong correlation with larger tumor size in cases of uterine leiomyomas [27]. According to Watanabe et al. [28], oncogenic RAS signaling modulates HMGA2 expression which determines the manifestation of epithelial phenotype of pancreatic cancer cells. Under stimulated differentiation (normal circumstance), overexpression of let- $7 \mathrm{~b}$ reduces ras and HMGA2 expression, resulting in inhibited cell proliferation and apoptosis induction. However, underexpression of let-7b and overexpression of c-Myc [29], transcriptionally induces Lin28B to suppress the maturation of let-7b microRNA precursors [30-31] which promotes genomic instability, cell proliferation and metastasis [32]. In normal tissues, reduced Phosphatase and tensin homologue (PTEN) expression is adduced to epigenetic events such as promoter methylation [33-34], phosphorylation and ubiquitination, while oxidation and acetylation reduce PTEN activity [35]. Overexpressions of PTEN via dowregulation of Let-7b in TPC have been reported in literature (Table 1). Several studies revealed that let-7b is underexpressed in TPC; ovarian cancer [36-38], cervical cancer [39] and breast cancer [40-41].

\subsection{Plasticity of miR-125b in Cancer Tissues}

Precursors of mature miRNA-125b which include pre-miR-125b-1 and pre-miRNA-125b-2 are located at chr11q24.1 and chr21q21.1, respectively [42]. More importantly, miR-125b is located at chromosome 11q23-24, a region recurrently identified and downregulated in breast, ovarian, and lung tumors [43-44]. In normal tissues, miR-125b reduces cell proliferation, motility, invasiveness and anchorage-dependent cell growth [45]. Its upregulation promotes cell proliferation, de-differentiation, and inactivation of apoptosis in cancers [46]. Interestingly, variation in miR-125b expression has been reported in different cancers under pathophysiological conditions [47-49]. This suggests that some miRNAs are tissue-specific or even cell-type-specific. This information explains, in part, the discordant reports in miRNA expression in some type of cancers [50]. MiR-125b is overexpressed in papillary thyroid cancer and underexpressed in anaplastic thyroid carcinomas, hepatocellular carcinoma (HCC) tissues and HCC cell lines [48] when compared with normal thyroid tissue [51]. Its levels are more reduced in oral squamous cell carcinoma (OSCC) tissues and cell lines compared with oral keratinocyte (NHOK) controls [49]. MiRNA-125b is regulated by transcriptional control of nuclear factor-kB [52-53]. Normally, activation of p53 during DNA damage or oncogene activation leads to cell cycle arrest or apoptosis [54]. Underexpression of miR-125b upregulates $\mathrm{p} 53$ and induces cell apoptosis (Le et al., 2009) while its over-expression inhibits the endogenous level of p53 and p21 resulting in malignant cell immortality.

According to Guan et al. [56], miR-125b decreases the proliferation of human ovarian cancer (OC) cells, and suppresses the growth of OC cells by targeting BCL3. MiR-125b, as a tumour suppressor, is down-regulated in biopsy specimens [57-58] through the ERBB2 and ERBB3 signaling [59] or by targeting the ETS1 gene [60]. It has also been reported to reduce the expression of MUC1 oncoprotein [61]. Mounting evidences suggest that it increases the resistance of cancer cells to anticancer drug [62], with resultant recurrence and metastasis (by targeting STARD13), particularly in triple negative breast cancer [63]. The observed metastasis could be due to the molecular interaction of miR-125b and mutant BRCA genes in complex genetic pathways (figure 1). MiR-125b has also been shown to be downregulated by approximately $30 \%$ in endometrioid endometrial cancer resulting to increased cell invasiveness, possibly through ERBB2 signaling [64]. The down-regulation of miR-125b in the endometrial cancer and TPC suggests that these cancers occur by a single pathway with the involvement of the female reproductive hormones. The dysregulation of miR-125b may be linked to some cases of infertility. According to Banzhaf-Strathmann and Edbauer [65], downregulation of miR-125b through ERBB2/3 signaling induces cell proliferation by Ras-mitogen activated protein kinase (MAPK) pathway which ultimately stalls apoptosis via the mammalian target of rapamycin (mTOR) pathway. In TPC, underexpression of miR-125b was observed; ovarian cancer $[36,37,66]$, cervical cancer [39,67-73] and breast cancer $[58,67,68,74]$.

\subsection{Modulation of miR-143/145 in Cancer}


Transcription factor, p53, controls cellular response to DNA damage by regulating cell cycle and apoptosis. Half of human cancers possess the mutated form of this transcription factor which regulates the transcription of several miRNAs [75]. In the event of DNA damage, interaction of $\mathrm{p} 53$ and $\mathrm{p} 68$ promotes the posttranscriptional maturation of several miRNAs such as miR-143 and miR-145 with growth-suppressive function [76]. MiRNAs, miR-143 and miR-145, develop a bicistronic cluster in $5 \mathrm{q} 33.1$ and are known to be inhibit cell proliferation and angiogenesis, and promote apoptosis [32,77]. Undetectable levels of MiR-143 and miR-145 in epithelium-derived cancer cell lines has been reported with detectable levels in normal human tissue. Due to their tumour suppressive capability of these miRNAs, the loss of posttranscriptional action via denaturation or mutation of $\mathrm{p} 53$ promotes malignancies in epithelial cell [78-80]). Repression of miR-143 or miR-145 leads to activation of the Ras oncogene in KRAS mutant pancreatic and colorectal cancers via Ras-responsive element-binding protein (RREB1) cleaving to miR-143/145 promoter [81]. The latter signaling pathway is supported by the findings of Hingorani et al. [82]. Despite the fact that modulation of K-RAS by miR-143 was detected in an epithelial cell type, miR-143 may also modulate K-RAS in mesenchymal cells. MiR-143 has been reported to be underexpressed in TPC; ovarian cancer [38], cervical cancer [67,68,83-89] and breast cancer [90,91]. More so, miR-145 is underexpression in ovarian cancer $[69,90,93]$, cervical cancer $[83,85-89]$ and breast cancer $[4,40,91,92,95]$.

\section{Dual Activity of over miR-214 Expression in TPC}

Chemoresistance, tumor progression, and metastasis have been observed in many malignancies (such as pancreatic, prostate, gastric, breast, cervical and ovarian cancers including malignant melanoma) which had overexpressions of miR-214 and downregulation of tumour suppressors target genes such as FAP2C, PTEN and p53 [96-103,108]. MiR-214 was also reported to be overexpressed in cervical and hepatocellular cancers by Sharma et al. [104]. Contrary to these reports, down-regulation of miR-214 was observed in human breast cancer tissues [105-111], ovarian cancer [38], and cervical cancer $[68,84,87,105]$. These contradicting reports might be due to the fact that miRNAs expressions vary in different tumor cells and sites even in the same organ, as also reiterated by Okoye [50]. More so, depending on the tumour stimulating factor, miRNA may function as a tumor suppressor in a neoplastic disease and oncomir in others. MiR-214 underexpression was suggested to upregulate RAS in ovarian cancer [112]. Deactivation and activation of Ras family members are antagonistically regulated by GTPase activating proteins (GAPs) and guanine nucleotide exchange factors (GEFs) [113,114]. Downregulation of miR-214 and upregulation of GALNT7 in cervical cancer was also reported by Peng et al. (2014). Other modulated regulons in ovarian cancer targets include: PTEN, RAS, SRC, BCL-2 [112] CCNL2; WDR8; WDR8 [73] and IKK [38], while that of cervical cancer include GALNT-7 [105,115] Plexin-B1 [96,115]. Targets such as PTEN and FAP2C are also modulated in breast cancer [105].

\section{Oncogenic miRNAs in TPC}

In TPC, upregulated oncogenic miRNAs include miR-21, miR-146a, miR-155, miR-182 and miR-200c (Table 2). Their roles in tumorigenesis in respect to cancers, especially TPC, are discussed below. More so, the interaction of these miRNAs and tumour suppressor equivalents and their target oncogenes in the emergence of TPC is shown in figure 1.

\subsection{Bi-Functional Activity of Mir-146a}

In humans, miR-146a resides on chromosome 5q33.3 [132]. It promotes cell proliferation and cell cycle progression [32]. It is up-regulated in LPS-stimulated macrophages and negatively modulates the Toll-like receptor-mediated immune response to forestall undue cell activation [133-135]. Overexpression of miR-146a is suggested to occur through by transcriptional repression of NF- $\mathrm{KB}$ family members $[133,136]$. Upregulation of miR-146a is not only observed in cervical cancer [71,83,89,137], but also upregulated in ovarian cancer [138], and breast cancer $[139,140]$. Upregulation of miR-146a in TPC activates cell cycle progression and proliferation via repression of NFkB activators IRAK1/ TRAF6 [133,141]. The TRAF6 signaling in TPC in turn recruits IKK complex which results in phosphorylation and degradation of the $\mathrm{ikB}$ inhibitor that ultimately activates NFkB dimmers [142-144] which suppresses BRCA 1 [145]. Suppressed BRCA1 expression is also associated with upregulated expression of high-mobility group proteins type A1 (HMGA1) and inhibitor of differentiation 4 (ID4) which regulates gene transcription and DNA conformation [146-148]. Inactivation of the BRCA1 gene in TPC may occur through a combination of complex mechanism or single mechanism such as somatic mutation, promoter methylation, haploinsufficiency, transcriptional inhibition and impairs homologous recombination [145]. More so, upregulation of miR-146a downregulates p53, tumor necrosis factor, FADD and TRADD which results in increased proliferation in both luminal and basal-like breast cancer cell lines [149].

Tumor cells exhibit morphological and phenotypical changes during cancer progression by a phenomenon known as epithelial-mesenchymal transition [153]. This phenomenon is observed in miR-146a activity. Just like miR-125b, miR-146a expression is suggested to differ in varied cancer tissues. For example, in Burkitts lymphoma lines, elevated level of miR-146a was seen with EBV-LMP1 expression [150,151], whereas reduced levels were 
observed in hormone-refractory prostate cancer [152], papillary thyroid carcinoma [154] and mesenchymal-like lung cancer cell lines [153]. MiR-146a upregulation reduces mesenchymal marker and elevates the epithelial marker in lung cancer cell lines which leads to reduction in migration and invasion of cancer cells, possibly by directly targeting the insulin receptor substrate 2 (IRS2) [153]. The reason for this varied expression is yet unclear.

\subsection{Mir-21 Activity in Malignancy}

MiRNA-21 possesses tumourigenic activity which are elevated in different types of cancers including glioblastoma [155], glioma [156] brain, breast, cervix (table 1), lung, liver, prostate, pancreas, and colon [37,58,99,157-160] where it promotes cell proliferation, angiogenesis, metastasis, escape from surveillance and inactivates apoptosis [32,158]. Haverty et al. [161] suggests that miR-21 is upregulated by gene amplification, a non-transcriptional mechanism, rather than promoter hyper-activation. However, some studies suggest that miR-21 expression is controlled by transcriptional and post-transcriptional modulation [161]. According to Hayashi et al.[162], miR-21 promotes branching morphogenesis possibly by regulating MMPs and targeting RECK and PDCD4. Some findings revealed over-expression of miR-21 in ovarian cancer $[38,66,93,163]$, cervical cancer $[67,83,85-87,99,164]$ and breast cancer $[36,40,57,58,93,99,158,165-168]$ through PTEN signaling (table 2).

\subsection{Regulation of Mir-155 in Cancer}

Overexpression of miR-155 has been reported in several neoplastic diseases such as hematopoietic cancers, breast, lung and colon cancer [169], especially through the downregulation of mutant p53 and tumor protein 53-induced nuclear protein 1 (TP53INP1) in breast tumours which promotes metastasis [170,171]. MiR-155 suppresses apoptosis and inhibits cell cycle arrest through a blockade of caspase-3 activity $[172,173]$. Its upregulation represses the RHOA gene, which serves a vital function in cell junction formation and sustenance. The RHOA gene, though yet to be validated in ovarian cancer, when underexpressed, results in lack of cell adhesion among mutated cells [32]. Interestingly, miR-155 is overexpressed in ovarian cancer [66,174], cervical cancer $[39,69,70-72,83,89,99]$ and breast cancer $[40,58,93,99,175]$.

\subsection{Oncogenic Activity of miR-182}

miR-182 is frequently overexpressed in human breast, ovarian and endometrial tumor tissues and cell lines [176-179] compared with that of healthy controls. Its oncogenic activity was revealed following the repression of FOXO1, which promotes proliferation of malignant cells and metastasis [176,180]. It represses the expression BRCA1 gene in the event of DNA damage response, thereby inhibiting DNA repair via poly adenosine diphosphate ribose polymerase 1 (PARP1) inhibition [181]. Evaluation of breast cancer cell lines revealed that miR-182 downregulates the metastasis suppressor missing-in-metastasis (MIM/MTSS1) which also inhibits cancer cell motility, invasiveness through inactivation of the cytoskeleton regulator RhoA. Additionally, miR-182 has been implicated in malignancies involving TGF $\beta$ and NFkB, pathway [182]. According to recent findings, miR-182 is overexpressed in ovarian cancer [183-186], cervical cancer $[67,84,68]$ and breast cancer $[187]$.

\subsection{Clonogenic and Tumorigenic Activity of Mir-200c}

Downregulation of miR-200c is observed in breast cancer stem cells, normal mammary stem or progenitor cells [188]. Its overexpression reduces clonogenic and tumour initiation activities in breast cancer stem cells which inhibits formation of mammary ducts through BMI-1 modulation [189]. The findings of Kan et al. [190] revealed that the expression of miR-200c is significantly overexpressed in serous epithelial ovarian cancer. According to Bendoraite et al. [191], miR-200c determines the epithelial phenotype of cancer cells by targeting the E-cadherin repressor proteins ZEB1 and ZEB2, and controlling oxidative stress via p38a [192]. Snowdon and his colleagues [193] also reported up-regulation of miR-200c in both endometrioid endometrial adenocarcinoma and complex atypical hyperplasia compared to normal control endometrium. Their work is in line with that of Lee et al. [194] and Park et al. [195] which revealed similar findings in cancerous tissues as well as endometrial adenocarcinoma cell. Upregulation of miR-200c in tri-reproductive cancer occur through the ZEB1/ZEB2 pathway. Other likely pathways may include targets genes such as TARDBP, PTEN and ZEB1. In literature, miR-200c was suggested to be overxpressed in ovarian cancer $[37,38,69,93,184,185]$, cervical cancer $[71,84,196]$ and breast cancer $[40,41]$. 
Table 1. Antitumorigenic miRNAs and their targets in TPC.

\begin{tabular}{|c|c|c|c|}
\hline miRNAs & Ovarian cancer & Cervical cancer & Breast Cancer \\
\hline Let 7b & $\begin{array}{c}\text { RAS, HMGA2 [38], } \\
\text { c-Myc [116] }\end{array}$ & RAS, NF $\kappa$ B, [117], XIAP [115] & RAS, HMGA2, LIN28, PEBP1 [117-121] \\
\hline miR-125b & $\begin{array}{c}\text { CSNK2A1 [36,37], FAM169B } \\
\text { [73], HIF-1 } \alpha, \text { VEGF [38], BCL3, } \\
\text { ERBB2, ERBB3 [65]. }\end{array}$ & $\begin{array}{c}\text { PIK3CD, PI3K, P-Akt, P-mTOR } \\
\text { [87], BAK-1 [117], ERBB2, } \\
\text { ERBB3 [65]. }\end{array}$ & $\begin{array}{c}\text { BMPR1B [74], ENPEP, CK2- } \alpha, \text { CCNJ, MEGF9 [45], } \\
\text { TP531NP1, TNFAIP3, BAK-1, CBF3, ABTB1 [120], } \\
\text { E2F3 [121]. }\end{array}$ \\
\hline miR-143 & ENO1; KIF1B; KRAS [73]. & $\begin{array}{c}\text { Bcl-2, ERK5/ MAPK7 [67,123], } \\
\text { KRAS, PIK3CA [124]. }\end{array}$ & ERK5, KRAS [125,126], ERBB3 [91]. \\
\hline miR-145 & $\begin{array}{c}\text { RERE; CTNNBIP1; FSCN1 } \\
\text { [158], HIF-1, VEGF [38], } \\
\text { P70S6K1, MUC-1 [127]. }\end{array}$ & $\begin{array}{c}\text { HLTF [128], MUC-1, IRS-1 } \\
\text { [115]. }\end{array}$ & $\begin{array}{c}\text { Muc-1 [129], RTKN [130], EGFR [131], c-Myc [129], } \\
\text { ERBB3 [91], PTEN, ZEB1, ZEB2 [120]. }\end{array}$ \\
\hline
\end{tabular}

In table 1 above, common target genes for the tumour suppressor miRNAs in TPC include RAS, HMGA2, ERBB2, ERBB3, BAK1, KRAS, ERK5/MAPK7, MUC-I, Bcl-2 and c-Myc. Crosstalk is suggested to exist through this target genes.

Table 2. Tumorigenic miRNAs and their targets in TPC

\begin{tabular}{|c|c|c|c|}
\hline miRNAs & Ovarian cancer & Cervical cancer & Breast Cancer \\
\hline $\operatorname{miR}-21$ & $\begin{array}{c}\text { PTEN, E2F1 [192,197], } \\
\text { YOD1, LOC150786, GPR64, } \\
\text { PLAG1, RP2, ADNP [13], } \\
\text { CLCA3P, SATB1 [13,36,37] }\end{array}$ & $\begin{array}{c}\text { PTEN [196], } \\
\text { MMPs [155,199,200], } \\
\text { PDCD4,TPM1 [201,202], } \\
\text { CCL20 [203]. }\end{array}$ & $\begin{array}{l}\text { BCL-2, TPM1, PDCD4, PTEN, MASPIN } \\
\text { [204,205-207]. } \\
\text { SEPINB5, Bc12, TPM1, NCAPG, OXSR1, } \\
\text { SEC23A [208]. }\end{array}$ \\
\hline miR-146a & IRAK1 and TRAF6 [138] & $\mathrm{NF} \kappa \mathrm{B}[83]$ & EZH2 [120], NF $\kappa$ B [136], p53 [149] \\
\hline miR-155 & $\begin{array}{c}\text { BACH1, ZNF652, RAB11FIF2, } \\
\text { ZNF537 } \\
\text { [13], CLDN1 [209]. } \\
\end{array}$ & $\begin{array}{l}\text { RhoA, TGF } \beta 1, \text { R-SMAD, } \\
\text { SMAD4 [32] RHEB, mTOR, } \\
\text { Cyclin D, RPS6KB2 [115]. }\end{array}$ & $\begin{array}{c}\text { RHOA [210] RAD51[211] } \\
\text { SOCS1 [3] } \\
\text { FOXO3a, APC [120], HK2 [209] }\end{array}$ \\
\hline $\operatorname{miR}-182$ & NRCAM; RGS17 [183,184] & DNMT3a [212] & FOXO1 [187], PFN1 [3], TCEAL7 [213] \\
\hline miR-200c & $\begin{array}{c}\text { TARDBP }[37,92,184,185] \\
\text { ZEB1; ZEB2; TARDBP [101], } \\
\text { TUBB3 [38]. }\end{array}$ & ZEB1 and ZEB2 [115,192] & $\begin{array}{c}\text { BM11,ZEB1,ZEB2 [188,214,216,217] PLC1, } \\
\text { SUZ12, FN1, LEPR, NTRK2, ARHGAP19, EphA2 } \\
\text { [3], ZEB I, CDH I, PTEN [121] }\end{array}$ \\
\hline
\end{tabular}

In table 2 above, common targets of oncogenic miRNAs in TPC include: TPM1, PDCD4, PTEN, NF $\kappa$ B, ZEB1, ZEB2, and RHOA.

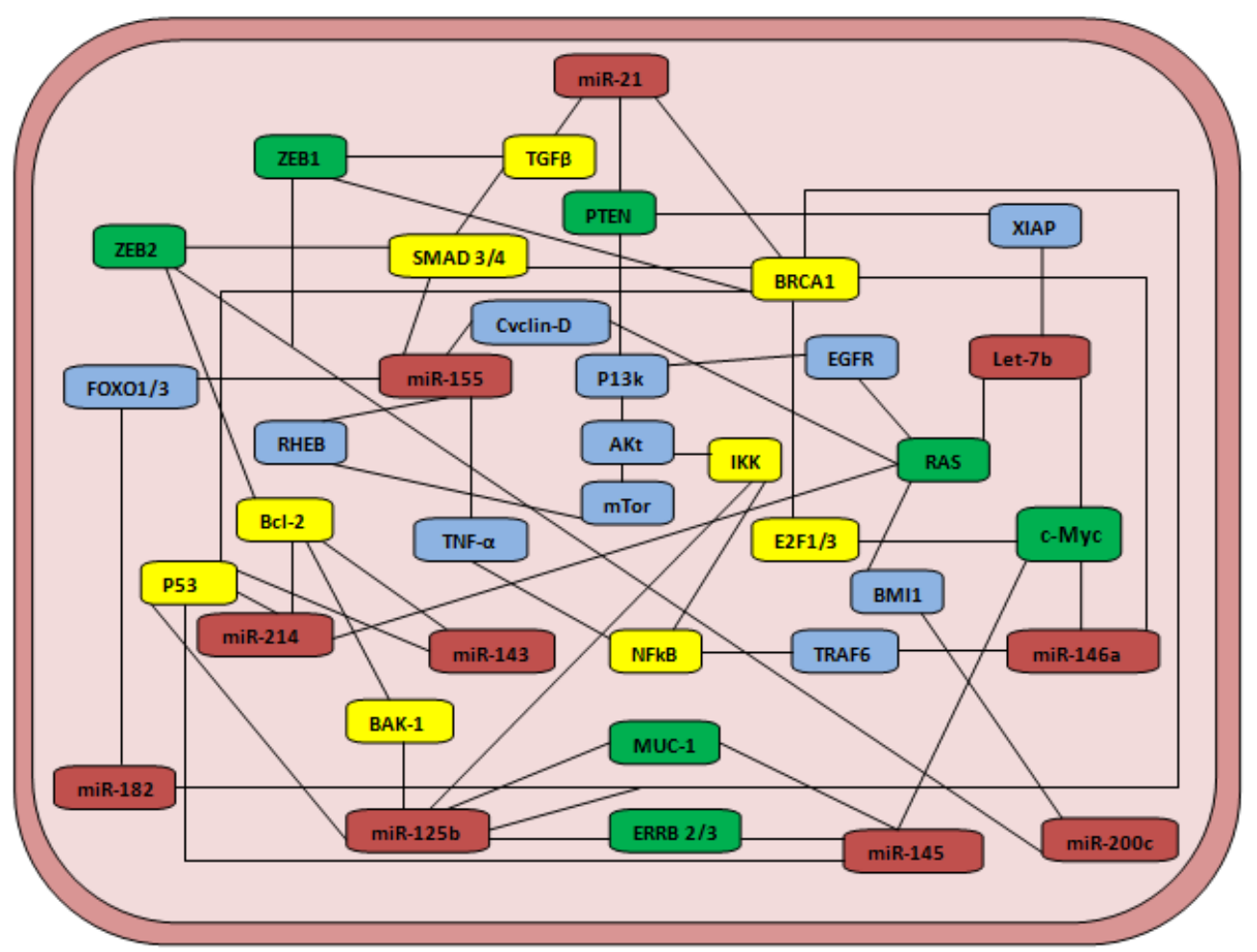

Figure 1. Cross-talk signaling pathways involving miRNA and target gene in tri-positive cancer 


\section{Inflammation and Mirna Expression}

Universally, chronic inflammatory conditions are believed to create the favourable microenvironment for malignancy initiation through a cascade of events. Examples include the link between: gastroesophageal reflux disease and esophageal cancer, atrophic gastritis and stomach cancer and inflammatory bowel diseases and colon cancer [217]. The chronic inflammatory due to infection (such as in Human papilloma virus) and irritation (radiation and mutagens) may encourage genomic lesions and tumor initiation. An efficient system through which immune cells and enzymes attack microbial infection is the synthesis of free radicals such as reactive oxygen intermediated (ROI), hydroxyl radical, superoxide and reactive nitrogen intermediates (RNI), nitric oxide and peroxynitrite. Interestingly, ROI and RNI result in oxidative damage and nitration of DNA bases which increases the risk of DNA mutations [218]. Mutagen induced DNA damage or oncogenic activation may either initiate cell DNA repair or death of initiated cells. In the event of enormous cell death as a result of repeated exposure to microbial infection or tissue trauma, lost cells must be replaced by undifferentiated reserve cells such as tissue stem cells through proliferation $[219,220]$. Concurrent DNA damage and cell division in chronic inflammation, in a bid to maintain homeostasis, may result in cancer due to the fact that cells that are dividing are more susceptible to mutations caused by DNA damage [221]. This is supported by the fact that miR-155 and miR-146a have been reportedly dysregulated in cases of chronic inflammation [222-226]. Hypothetically, dysregulation of seven out of the ten discussed miRNAs may be a strong indication of imminent TPC. Thus, their expressions can be used to predict cancer in high risk individuals with chronic inflammation. These miRNAs might be responsible for the metastasis of the individual cancers to other sites.

\section{Functional Patterns of Tumour Initiating Cells}

The cancer stem cells, also referred to as tumour initiating cells (T-ICs), are described as cancer cells that have the ability to self-renew and differentiate into other malignant stem cells, including cells that will lead to the emergence of diverse phenotypes of cancer cells called transient amplifying cells [227-230]. These cells are left behind and intact following conventional therapy, which according to cancer stem cell hypothesis, eventually repopulate the tumor [231] and resulting in tumor heterogeneity, progression and metastasis [232]. The cancer stem cells are thought to be resistant to conventional therapy through mechanisms including drug efflux and resistance to DNA damage $[232,233]$. Though, the source of cancer stem cells is largely unknown, some studies suggest that they originate from either adult tissue stem cells or tumorigenic progenitor cells [234]. Cancer stem cells can be identified from solid human cancers such as breast, brain, bone, lung, melanomas, prostate, colon, pancreas, liver, and head and neck [235-245]. According to the current cancer stem cell hypothesis, tumors are organized in cell hierarchies composed of T-ICs, cancer cells and differentiated cells [246]. Furthermore, the hypothesis also posits that tumor cells are structured in a hierarchy and that only cells that exist at the apex of the hierarchy can regenerate the tumor when implanted into immunocompromised mice and in so doing reproduce the heterogeneity of the original patient tumor [247]. Stem cells live longer than many differentiated cells and may therefore be exposed to damaging agents for a longer time, allowing accumulation of mutations that can result in transformation [248,249].

\section{Mirna Regulation in Tumour Initiating Cells and Tumour Cells}

Tumor - initiating cells (TICs) display characteristics of normal adult stem cells such as the capability for self-renewal and differentiation [232]. Although pathways that regulate self-renewal are tightly controlled in normal stem cells, in tumour-initiating cells they may be constitutively activated or improperly regulated through genetic and/or epigenetic changes, leading to uncontrolled growth [250]. This is further supported by the fact that knockout of Dicer (the enzyme that controls the maturation of pre-miRNAs) in mice is embryonically fatal [251] due to failure in cell differentiation [252]. Reports show that miRNAs modulate the properties of embryonic stem (ES) and tissue stem cells in a variety of eukaryotic organisms $[253,254]$. MicroRNA expressions vary between normal tissues and tumor tissues and among tumor types [99,170,255-258]. This is buttressed by the fact that BRCA cells with a higher prevalence of T-ICs have been revealed to possess distinct miRNA expression profiles that may contribute to the maintenance of stem cell properties. Mammalian let-7 expression is underexpressed in human BRCA T-ICs and significantly overexpressed in differentiated cells. Let-7 represses self-renewal by targeting H-RAS and promotes differentiation by targeting HMGA2 [259]. More evidence of miRNA involvement in cancer stem cell activity was revealed when high and low expressions of miR-22 and miR-205, and miR-93 and let-7 were observed in progenitor cells compared to differentiated cells [260], respectively. The findings of Wang et al. [261] suggest that the function of leukemia-initiating cells are PTEN dependent while normal HSCs function are PTEN independent [261].

Recent findings reveal some variation in miRNA expression between T-ICs and tumour cells. For example, under-expression of miR-200c was observed in T-ICs [188] when compared with tumours cells which had over-expression of the miRNA [190-196]. MiR-200c 
under-expression in T-ICs induces down-regulation of target genes such as FN1 and ZFHX1B [188]. Tumour initiating cells also exhibit under-expression of miR-21 [262] when compared with other cancers [155-160]. More so, miR-125b is upregulated in T-ICs with concurrent down-regulation of target genes such as U251 GPC4, TAZ, MSI1 [263] when compared with other cancers, particularly TPC (Table 1). The variation in miR-125b between T-ICs and normal cancer cells may be responsible for the reported cancer resistance to therapy, especially among patients with Triple Negative Breast Cancer (TNBC) [62,63]. Let-7b is over-expressed in some solid tumours [20-26], but under-expressed in T-ICs [16,17] and TPC [36-41]. The similarity in let-7b expression in T-ICs and TPC accounts for the lower number of cancer relapse among TPC patients undergoing let-7 directed therapy. This is due to the fact that the destruction of tumour cells by some anti-cancer drugs also eliminates the T-ICs. Despite the similarity in Let-7b expression, the target genes involved in T-ICs self-renewal and proliferation (COL2A1, GLI3, KLF4) [264] vary from that observed target genes in TPC (Table 1).

\section{Conclusions}

MiRNA crosstalk occurs through a number of target genes leading to a complex regulating network which could result in tri-positve cancer. In TPC, upregulated oncogenic miRNAs includes: miR-21, miR-146a, miR-155, miR-182 and miR-200c while the downregulated tumour suppressor miRNAs includes: let-7b, miR-125b, miR-143 and miR-145. The dual activity (controversial reports) of miR-214 in TPC suggests that it can function both as a tumour suppressor and oncogene, thus its tight regulation. MiRNAs interact with each other through a range of target genes such as ERK5, BRCA1, PTEN, Muc-1, ERRB2/3, ZEB1/2, RAS, Bcl-2 and c-Myc among others, mostly through the P13k/Akt signaling pathway. Furthermore, upregulation of miR-146a and miR-182, and downregulation of miR-125b were observed in the repression of BRCA expression in TPC. Furthermore, an understanding of the variation in miRNA and target genes expression between T-ICs and other cancers or tumour cells may provide solutions to the observed failure in therapy during patient management. Thus, proper investigation of these miRNAs and target genes in high risk individuals may aid cancer prediction and early diagnosis of cancer which will in turn reduce mortality due to cancer.

\section{Abbreviations}

Bak1: Bcl-2 antagonist killer 1, Bcl-2: B-Cell lymphoma 2, CLDN1: claudin-1, c-Myc: Myelocytomatosis, E2F3: E2F transcription factor 3, ERRB/EGFR: epidermal growth factor receptor, FOXO 1/3: Forkhead box protein 1/3, HMGA2: High mobility group A2, HMGB3: High mobility group box 3, IKK: ikB kinase Chl1, JNK: c-Jun N-terminal kinase, MAPK/ERK: Mitogen-activated protein kinase/Extracellular signal-regulated kinase, Muc-1: Mucin-1, NCAPG: non-SMC condensin I complex subunit G, NFkB: Nuclear Factor-kappa B,OXSR1: oxidative-stress responsive 1 (OXSR1), PDCD4: Programmed cell death 4, PTEN: Phosphatase and tensin homolog, RAS: Rat sarcoma, RHEB: Ras homolog enriched in brain, RHOA: Ras homolog gene family member A, SMAD: Mother against decapentaplegic homolog, TGF $\beta$ R2: transforming growth factor- $\beta$ receptor II, TPM1: Tropomyocin 1 VEGF: vascular endothelial growth factor, XIAP: X-linked inhibitor of apoptosis, ZEB 1/2: zinc finger E-box $1 / 2$.

\section{REFERENCES}

[1] D. Di Leva, C.M. Croce. Roles of small RNAs in tumor formation. Trends in Molecular Medicine.16, 257-267, 2010. doi:10.1016/j.molmed.2010.04.001

[2] A. Colaprico,C. Cava, G. Bertoli, G. Bontempi, and I. Castiglioni. Integrative Analysis with Monte Carlo Cross-Validation Reveals miRNAs Regulating Pathways Cross-Talk in Aggressive Breast Cancer. BioMed Research International. 2015.2 Available from: http://dx.doi.org/10.1155/2015/831314. Accessed on $2 / 4 / 2016$

[3] J.O. Okoye, and F.O. Okoye. MiRNA and Target Oncogene Regulation in Triple Negative Breast Cancer: An Age, Ethnic and Environmental Related Neoplastic Event. JCTI. 2(2), 66-80, 2015.

[4] S.W. Fu, L. Chen, Y. G. Man. miRNA Biomarkers in Breast Cancer Detection and Management. Journal of Cancer.2, 116-122, 2011.

[5] C.M. Croce. Oncogenes and cancer.The New England Journal of Medicine. 358 (5).502-511, 2008.

[6] F.P.Liebens,B.Carly, A. Pastijn, and S. Rozenberg. Management of BRCA1/2 assosiatedbreast cancer: a syste-matic qualitative review of the state of knowledge. Eur. J. Cancer. 43(2), 238-57, 2007.

[7] R. Rheim, C. Fischer, K. Bosse, Wappenschmidt and K. Schmutzler. Increased risk of cervical cancer in high-risk families with and without mutations in the BRCA1 and BRCA2 genes. American Society of Clinical Oncology. Journal of clinical oncology.25 (18S), 5588, 2007.

[8] K. Kumar, A.K. Abbas,N. Fausto, and J.C Aster. (2010). Robbins and Cotran pathologic basis of disease, 8th ed. Philadelphia, PA: Saunders Elsevier.

[9] I.P Ewald, P.R Izetti, F.R Vargas,M.A. Moreira. Prevalence of the BRCA1 founder mutation c.5266dup in Brazilian individuals at risk for the Hereditary Breast and Ovarian Cancer Syndrome.Herd.Cancer Clin.Pract.9(1), 2,2011.

[10] M. Bar, S.K. Wyman, B.R. Fritz,et al. Microrna discovery and profiling in human embryonic stem cells by deep sequencing of small rna libraries. Stem Cells.26, 2496-505, 2008. 
[11] D.R. Barh, B. Malhotra, Ravi and P. Sindhurani. Microrna let-7: an emerging next-generation cancer therapeutic. Current Oncology.17, 70-80, 2010.

[12] J. Takamizawa, H. Konishi, K. Yanagisawa, et al. Reduced expression of the let-7 micrornas in human lung cancers in association with shortened postoperative survival. Cancer Res. 64, 3753-6, 2004.

[13] N. Dahiya, C.A. Sherman-Baust, T.L. Wang, B. Davidson, I. Shih, Y. Zhang, W.R. Wood, K.G Becker, P.J. Morin. MicroRNA expression and identification of putative miRNA targets in ovarian cancer. PLoS One, 3:e2436, 2008.

[14] A.J. O’Hara, L. Wang, B. J. Dezube, W.J. Harrington, B. Jr, Damania and D.P. Dittmer. Tumor suppressor microRNAs are underrepresented in primary effusion lymphoma and Kaposi sarcoma. Blood.113, 5938-5941, 2009.

[15] M. Guled, L. Lahti, P.M. Lindholm, K. Salmenkivi, I. Bagwan, A.G. Nicholson, and S. Knuutila. CDKN2A, NF2, and JUN are dysregulated among other genes by miRNAs in malignant mesothelioma - A miRNA microarray analysis. Genes, Chromosomes \& Cancer.48, 615-623, 2009.

[16] P. Dalerba,R.W. Cho, andM.F. Clarke. Cancer stem cells: models and concepts. Annu Rev Med.58, 267-284, 2007.

[17] N.A. Lobo, Y. Shimono, D. Qian, and M.F. Clarke. The biology of cancer stem cells. Annu Rev Cell Dev Biol. 23, 675-699, 2007.

[18] S.M. Park, S. Shell, A.R. Radjabi, et al. Let-7 prevents early cancer progression by suppressing expression of the embryonic gene HMGA2. Cell Cycle.6, 2585-2590, 2007.

[19] B. Boyerinas, S.M. Park, N. Shomron,et al. Identification of let-7-regulated oncofetal genes. Cancer Res. 68, 25872591,2008

[20] J. Nishino,I. Kim,K. Chada, and S.J. Morrison. Hmga2 promotes neural stem cell self-renewal in young, but not old, mice by reducing p16Ink4a and p19Arf expression. Cell.135, 227-39, 2008.

[21] C.J. Lengner, F.D. Camargo, K. Hochedlinger,et al. OCT4 expression is not required for mouse somatic stem cell self-renewal. Cell Stem Cell. 1, 403-415, 2007.

[22] G. Giannini, C.J. Kim,L. Di Marcotullio, et al. Expression of the HMGI(Y) gene products in human neuroblastictumours correlates with differentiation status. Br J Cancer.83, 15031509,2000 .

[23] G. Chiappetta,A. Bandiera,M.T. Berlingieri,et al. The expression of the high mobility group HMGI (Y) proteins correlates with the malignant phenotype of human thyroid neoplasias. Oncogene.10, 1307-1314, 1995.

[24] N. Abe, T. Watanabe, Y. Suzuki, et al. An increased highmobility group A2 expression level is associated with malignant phenotype in pancreatic exocrine tissue. $\mathrm{Br} \mathrm{J}$ Cancer.89, 2104-2109, 2003.

[25] V.K. Sarhadi, H. Wikman, K. Salmenkivi et al. Increased expression of high mobility group A proteins in lung cancer. $\mathrm{J}$ Pathol.209, 206-212, 2006.

[26] F. Yu,H. Yao,P. Zhu,X. Zhang,Q. Pan,C. Gong,Y. Huang, X. $\mathrm{Hu}, \mathrm{F}$. Su, J. Lieberman, et al. Let-7 regulates self renewal and tumorigenicity of breast cancer cells. Cell.131, 1109-
$1123,2007$.

[27] Y. Peng,J. Laser,G. Shi,et al. (2008).Antiproliferative effects by let-7 repression of high-mobility group A2 in uterine leiomyoma. Mol Cancer Res. 6, 663-673.

[28] S. Watanabe, Y. Ueda, S. Akaboshi, Y. Hino, Y. Sekita, and M. Nakao. HMGA2 maintains oncogenic RAS-induced epithelial-mesenchymal transition in human pancreatic cancer cells. American Journal of Pathology.174, 854-868, 2009.

[29] T.C. Chang, D. Yu, Y.S. Lee,et al. (2008). Widespread microrna repression by Myc contributes to tumorigenesis. Nat Genet. 40, 43-50.

[30] T.C. Chang, L.R. Zeitels, H.W. Hwang et al. Lin-28B transactivation is necessary for Myc-mediated let-7 repression and proliferation. Proceedings of the National Academy of Sciences of the United States of America, 106(9), 3384-3389, 2009.

[31] E. Piskounova, C. Polytarchou, J. E. Thornton et al. Lin28A and Lin28B inhibit let-7 microRNA biogenesis by distinct mechanisms, Cell. 147, 1066-1079, 2011.

[32] Y. Gómez-Gómez, J. Organista-Nava and P. Gariglio. Deregulation of the miRNAs Expression in Cervical Cancer: Human Papillomavirus Implications. BioMed Research International. 2013, Article ID 407052, 15 pages http://dx.doi.org/10.1155/2013/407052

[33] J. M. García, J. Silva, C. Peña et al. Promoter methylation of the PTEN gene is a common molecular change in breast cancer. Genes Chromosomes and Cancer. 41(2), 117-124, 2004.

[34] Y. H. Kang, S. L. Hye, H. K. Woo. Promoter methylation and silencing of PTEN in gastric carcinoma. Laboratory Investigation. 82(3), 285-291, 2002.

[35] J. E. Fata, S. Debnath, E. C. Jenkins, Jr, and M. V. Fournier. Nongenomicmechanisms of PTEN regulation. International Journal of Cell Biology. vol. 2012, Article ID 379685, 10 pages, 2012.

[36] H. Yang,W. Kong,L. He,J.J. Zhao, J.D. O'Donnell,J. Wang, R.M. Wenham, D. Coppola, P.A. Kruk, S.V. Nicosia and J.Q. Cheng. MicroRNA expression profiling in human ovarian cancer. MiR-214 induces cell survival and cisplatin resistance by targeting PTEN. Cancer Research. 68, 425-433, 2008.

[37] E.J. Nam, H. Yoon, S.W. Kim et al. MicroRNA expression profiles in serous ovarian carcinoma. Clinical Cancer Research, 14(9), 2690-2695, 2008.

[38] Y. Kinose, K. Sawada,K. Nakamura andT. Kimura. The role of miRNAs in Ovarian cancer. Biomedical Research. International 2014 (2014): 1-11. Doi: 10.1155/2014/249393. Article Id: 249393.

[39] B.H. Li, J.S. Zhou, F. Ye, X.D. Cheng, C.Y. Zhou and W.G. Lu. Reduced miR-100 expression in cervical cancer and precursors and its carcinogenic effect through targeting PLK1 protein. European J. Cancer.47, 2166-2174, 2011.

[40] L. Cascione and P. Gasparini. Integrated microRNA and mRNA signatures associated with survival in triple negative breast cancer. PLoS One.2013, 8, e55910, 2013.

[41] S.M. Chun, P. Hee-Jung and K. Chul Hwan. Insun Kim. The 
Significance of MicroRNA Let-7b, miR-30c, and miR-200c Expression in Breast Cancers. Korean Journal of Pathology.45, 354-360 http://dx.doi.org/10.4132/KoreanJPat hol.2011.45.4.354,2011.

[42] A.I. Pogue,J.G. Cui, Y.Y. Li, Y. Zhao,F. Culicchia and W.J. Lukiw. Micro RNA-125b (miRNA-125b) function in astrogliosis and glial cell proliferation.NeurosciLett.476, 18$22,2010$.

[43] M. Negrini, D. Rasio, G.M. Hampton, S. Sabbioni, S. Rattan,S.L. Carter and A.L. Rosenberg, et al. Definition and refinement of chromosome 11 regions of loss of heterozygosity in breast cancer: identification of a new region at 11q23.3. Cancer Research.55, 3003-3007, 1995.

[44] D. Rasio, M. Negrini, G. Manenti, T. A. Dragani and C.M. Croce. Loss of heterozygosity at chromosome $11 \mathrm{q}$ in lung adenocarcinoma: identification of three independent regions. Cancer Research. 55, 3988-3991, 1995.

[45] A. Feliciano, J. Castellvi, A. Artero-Castro, J.A. Leal, C. Romagosa,J. Hernandez-Losa, et al. miR-125b acts as a tumour suppressor in Breast Tumorigenesis via its novel Direst targets ENPEP, CK2- $\alpha$ CCNJ, and MEGF9. Plos ONE. 8(10): e76247, 2013. Doi.: 10.1371/journal.pone.0076247

[46] K. Huang, S. Dong, W. Li, Z. Xie. The expression and regulation of microRNA-125b in cancers. Acta Biochimicaet Biophysica Sinica. 45, 803-805, 2013.

[47] M.R. Vriens, J. Weng, I. Suh, N. Huynh, M.A. Guerrero, W.T. Shenand Q.Y. Duh, et al. MicroRNA expression profiling is a potential diagnostic tool for thyroid cancer. Cancer.118, 3426-3432, 2012.

[48] H.Y.Jia, Y.X. Wang,W.T. Yan,H.Y. Li,Y.Z. Tian, S.M. Wang and H.L. Zhao. MicroRNA- 125b Functions as a Tumor Suppressor in Hepatocellular Carcinoma Cells. International journal of Molecular Sciences.13, 8762-8774, 2012.

[49] B.J. Henson, S. Bhattacharjee, D.M. 'Dee, E. Feingold and S.M. Gollin. Decreased expression of miR-125b and miR-100 in oral cancer cells contributes to malignancy. Genes Chromosomes Cancer.48, 569-582, 2009.

[50] J.O. Okoye. Discordant Reports of miRNA Expression in Cervical Cancer: An Upshot of Overlapping Factors Research In Cancer and Tumor. 4(1), 15-23, 2015. DOI: $10.5923 /$ j.rct.20150401.03

[51] P. Pallante, R. Visone, M. Ferracin, A. Ferraro, M.T. Berlingieri, G. Troncone and G. Chiappetta, et al. MicroRNA deregulation in human thyroid papillary carcinomas. EndocrineRelatedCancer.13, 497-508, 2006.

[52] E. Tili, J.J. Michailleand C.M. Croce. MicroRNAs play a central role in molecular dysfunctions linking inflammation with cancer. Immunological Review. 253, 167-184, 2013.

[53] W.J. Lukiw. NF-kB-regulated, proinflammatorymiRNAs in Alzheimer's disease. Alzheimers Research and Therapy. 4, 47-53, 2012.

[54] W. D. Foulkes. p53-master and commander. New England Journal of Medicine. 357, 2539-2541, 2007.

[55] M.T. Le,C. Teh, N. Shyh-Chang,H. Xie,B. Zhou,V. Korzh and H.F. Lodish, et al. (2009). MicroRNA-125b is a novel negative regulator of p53. Genes Dev. 23, 862-876.

[56] H.Guan, L. Xie, F. Leithäuser, L. Flossbach, P. Möller, T.
Wirth and A. Ushmorov. KLF4 is a tumor suppressor in B-cell non-Hodgkin lymphoma and in classic Hodgkin lymphoma. Blood. 116, 1469-1478, 2010.

[57] M.D. Mattie, C.C. Benz,J. Bowers, K. Sensinger,L. Wong, G.K. Scott, V. Fedele, D. Ginzinger, R. Getts and C. Haqq. Optimized high-throughput microRNA expression profiling provides novel biomarker assessment of clinical prostate and breast cancer biopsies. Molecular Cancer.5, 24, 2006.

[58] M.V. Iorio,M. Ferracin,C.G. Liu,A. Veronese,R. Spizzo,S. Sabbioniand E. Magri, et al. MicroRNA gene expression deregulation in human breast cancer. Cancer Res 2005, 65: 7065-7070, 2005.

[59] G.K. Scott, A. Goga, D. Bhaumik, C.E. Berger,C.S. Sullivan, C.C. Benz. Coordinate suppression of ERBB2 and ERBB3 by enforced expression of micro-RNA miR-125a or miR-125b. Journal of Biology and Chemistry. 282, 1479-1486, 2007.

[60] Y. Zhang, L.X. Yan, Q.N. Wu, Z.M. Du,J. Chen, D.Z. Lia, M.Y. Huang, J.H. Hou, Q.L. Wu, M.S. Zeng, W.L. Huang, Y.X. Zeng, J.Y, J.Y. Shao. miR-125b is methylated and functions as a tumor suppressor by regulating the ETS1 proto-oncogene in human invasive breast cancer. Cancer Research. 71, 3552-3562, 2011.

[61] H. Rajabi, C. Jin, R. Ahmad, C. McClary, M.D. Joshi, D. Kufe, Mucin 1 oncoprotein expression is suppressed by the miR-125b ONCOMIR. Genes Cancer. 1, 62-68, 2010.

[62] H. Wang, G. Tan, L. Dong, L. Cheng, K. Li, Z. Wang, H. Luo. Circulating MiR- $125 \mathrm{~b}$ as a marker predicting chemoresistance in breast cancer. PLoS One.7:e34210, 2012.

[63] F. Tang, R. Zhang,Y. He,M. Zou,L. Guo,T. Xi. MicroRNA-125b induces metastasis by targeting STARD13 in MCF-7 and MDA-MB-231 breast cancer cells. PLoS One. 7:e35435, 2012.

[64] C. Shang, Y.M. Y.M. Lu,L.R. Meng. MicroRNA-125b down-regulation mediates endometrial cancer invasion by targeting ERBB2. Med SciMonit.18, 149-155, 2012.

[65] J. Banzhaf-Strathmann and D. Edbauer. Good guy or bad guy: the opposing roles of microRNA $125 \mathrm{~b}$ in cancer. Cell Communication and Signaling 2014 12:30, 2014. doi: 10.1186/1478-811X-12-30. Available at http://www.biosign aling.com/content/12/1/30. Accessed on 18/12/2015

[66] A. Laios, S.O. Toole,R. Flavin,C. Martin,L. Kelly and M. Ring.. Potential role of miR-9 and miR-223 in recurrent ovarian cancer. Molecular Cancer.7, 35, 2008. doi: 10.1186/1476-4598-7-35. Available from: http://www.molec ular-cancer.com/content/7/1/35

[67] W.O.Lui, N. Pourmand, B.K. Patterson and A. Fire. Patterns of known and novel small RNAs in human cervical cancer. Cancer Research. 67(13): 6031-43, 2007.

[68] V. Villegas-Ruiz, S. Juárez-Méndez, O.A. Pérez-González, H. Arreola, L. Paniagua-García, L. and M. Parra-Melquiadez. Heterogeneity of microRNAs expression in cervical cancer cells: over-expression of miR-196a. Int. J. Clin. Exp. Pathol. 7(4), 1389-1401, 2014.

[69] J. Ahmada, E. Seyed, Hasnainb, A. Maqsood, Siddiquia, A. Maqusood, M.C. Javed and A.A. Abdulaziz.. MicroRNA in carcinogenesis \& cancer diagnostics: A new paradigm. Indian J Med Res. 137, 680-694,2013

[70] C.B. Lajer, E. Garnæs, L. Friis-Hansen, B. Norrild, M.H. 
Therkildsen, M. Glud, et al. The role of miRNAs in human papilloma virus (HPV)-associated cancers: bridging between HPV-related head and neck cancer and cervical cancer. British Journal of Cancer. 106(9), 1526-1534, 2012. doi: 10.1038/bjc.2012.109

[71] S.M. Wilting, W. Verlaat, A. Jasper, et al. Methylation mediated transcriptional repression of microRNAs during cervical carcinogenesis.Epigenetics.8, 220-228, 2013.

[72] D. Witten, R. Tibshirani, S.G. Gu, A. Fire and W.O. Lui. Ultra-high throughput sequencing-based small RNA discovery and discrete statistical biomarker analysis in a collection of cervical tumours and matched controls. BMC Biol.8, 58, 2010.

[73] L. Chen, Zhang, Q. Hao, (2013). Candidate microRNA biomarkers in human epithelial ovarian cancer: systematic review profiling studies and experimental validation. Cancer Cell International. 13, 86, 2013. http://www.cancerci.com/co ntent/13/1/86

[74] P. Sætrom, J. Biesinger, S. Li, et al. A risk variant in a miR-125b binding site in BMPR1B is associated with breast cancer pathogenesis. Cancer Res, 69, 7459-65, 2009.

[75] M.D. Jansson, A.H. Lund. MicroRNA and cancer. Molecular Oncology. 6, 590-610, 2012.

[76] H.I. Suzuki, K. Yamagata, K. Sugimoto, T. Iwamoto, S. Kato, K. Miyazono. Modulation of microRNA processing by $\mathrm{p} 53$. Nature.460, 529-533, 2009.

[77] L. Wan, L. Zhang, K. Fan, J. Wang. miR-27b targets Limk1 to inhibit growth and invasion of NSCLC cells. Molecular Cellular Biochemistry. 390, 85-91, 2014.

[78] Y. Akao,Y. Nakagawa, T. Naoe. MicroRNAs 143 and 145 are possible common onco-microRNAs in human cancers. Oncology Report, 16, 845-850, 2006.

[79] T. Takagi, A. Iio, Y. Nakagawa, T. Naoe, N. Tanigawa, Y. Akao. Decreased expression of microRNA-143 and -145 in human gastric cancers. Oncology, 77, 12-21, 2009.

[80] O.A. Kent, R.R. Chivukula, M. Mullendore, E.A. Wentzel, G. Feldmann, K.H. Lee, S. Liu, S.D. Leach, A. Maitra, J.T. Mendell. Repression of the miR-143/145 cluster by oncogenic Ras initiates a tumor-promoting feed-forward pathway. Genes and Development. 24, 2754e2759, 2010.

[81] S.R. Hingorani, D.A. Tuveson. Rasredux: rethinking how and where Ras acts. Current Opinion Genetics and Development. 13, 6-13, 2003.

[82] X. Wang, S. Tang, S.Y. Le. Aberrant expression of oncogenic and tumor-suppressive microRNAs in cervical cancer is required for cancer cell growth. PLoS One. 3(7): e2557, 2008.

[83] I. Martinez, A.S. Gardiner, K.F. Board, F.A. Monzon, R.P. Edwards, S.A. Khan. Human papillomavirus type 16 reduces the expression of microRNA-218 in cervical carcinoma cells. Oncogene. 27(18), 2575-82, 2008. doi:10.1038/sj.onc.12109 19.

[84] P.M.Pereira, J.P. Marques, A.R. Soares, L. Carreto, M.A.S. Santos. MicroRNA expression variability in human cervical tissues. PLoS One. 5(7), e11780, 2010.

[85] X. Zhang, G. Wan, F.G. Berger, X. He, X. Lu. The ATM kinase induces microRNA biogenesis in the DNA damage response. Molecules and Cell. 41, 371e383,2011

[86] Y. Cui, Z.F. Xiao,J. Han, J. Sun, W.Y. Ding, Y.N. Zhao, B. Chen, et al.. MiR- 125b orchestrates cell proliferation, differentiation and migration in neural stem/ progenitor cells by targeting Nestin. BMC Neuroscience.13, 116, 2012.

[87] T.C. Chang, E.A. Wentzel, O.A. Kent et al. Transactivation of miR- 34a by 53 broadly influences gene expression and promotes apoptosis. Mol Cell. 26(5), 745-52, 2007.

[88] G.Reshmi, M.R. Pillai. Interplay Between HPV Oncoproteins and MicroRNAs in Cervical Cancer, Human Papillomavirus and Related Diseases - From Bench to Bedside - Research aspects. Dr. Davy VandenBroeck (Ed). 2012. Available from: http://www.intechopen.com/books/human-papillomavirus-an d-related-desease: Acessed on 20/10/15

[89] E. Aydoğdu, A. Katchy, E. Tsouko, C.Y. Lin, L.A. Haldosén, L. Helguero, C. William. MicroRNA-regulated gene networks during mammary cell differentiation are associated with breast cancer. Carcinogenesis. 33(8), 1502-1511, 2012. DOI: $10.1093 /$ carcin/bgs161.

[90] X. Yan, X. Chen, H. Liang, T. Deng, W. Chen, S. Zhang, et al. miR-143 and miR-145 synergistically regulate ERBB3 to suppress cell proliferation and invasion in breast cancer. Molecular Cancer.13, 220, 2014. doi: 10.1186/1476-4598-13 -220 .

[91] M.V. Iorio, R. Visone,G. Di Leva,V. Donati, F. Petrocca,P. Casalini,C. Taccioli,S. Volinia, C.G. Liu,H. Alder, G.A. Calin, S. Menard, C.M. Croce, (2007). MicroRNA signatures in human ovarian cancer. Cancer Research.67, 8699-8707, 2007.

[92] G. Di Leva,C.M. Croce.The role of microRNAs in the tumorigenesis of ovarian cancer. Frontiers in Oncology.3, 2013. doi: 10.3389/fonc.2013.00153. http://www.frontiersin. org/Oncology/editorialboard

[93] J.W. Lee, C.H. Choi, J.J. Choi, Y.A. Park, S.J. Kim, S.Y. Hwang. Altered MicroRNA expression in cervi-calcarcinomas. Clin Cancer Res. 14, 2535-25, 2008.

[94] J. Radojicic, A. Zaravinos,T. Vrekoussis,M. Kafousi,D.A. Spandidos, E.N. Stathopoulos. MicroRNA expression analysis in triple negative (ER, PR and Her2/neu) breast cancer // Cell Cycle. 10, 507-517,2011

[95] R. Qiang, F. Wang, L.Y. Shi, M. Liu, S. Chen, H.Y. Wan, et al. Plexin-B1 is a target of miR-214 in cervical cancer and promotes the growth and invasion of HeLa cells. Int. J. Biochem. Cell Biol. 43, 632-641, 2011.

[96] T. Ueda, S. Volinia, H. Okumura, M. Shimizu, C. Taccioli, S. Rossi, et al. Relation between microRNA expression and progression and prognosis of gastric cancer. A microRNA expression analysis. Lancet Oncol. 11, 136-146, 2010.

[97] E. Penna, F. Orso, D. Cimino, E. Tenaglia, A. Lembo, E. Quaglino et al. MicroRNA-214 contributes to melanoma tumour progression through suppression of TFAP2C. EMBO Journal 30, 1990-2007, 2011.

[98] S. Volinia, G. A. Calin, C.-G.Liu, et al. A microRNA expression signature of human solid tumors defines cancer gene targets," Proceedings of the National Academy of Sciences of the United States of America. 103 (7), 2257-2261, 2006.

[99] C. Blenkiron, L.D. Goldstein, N.P. Thorne, I. Spiteri, S.F. 
Chin, M.J. Dunning, et al. MicroRNA expression profiling of human breast cancer identifies new markers of tumor subtype. Genome Biol. 8, R214, 2007.

[100] L.F. Sempere, M. Christensen, A. Silahtaroglu, M. Bak, C.V. Heath, G. Schwartz, et al. Altered MicroRNA expression confined to specific epithelial cell subpopulations in breast cancer. Cancer Research. 67, 11612-11620, 2007.

[101] X Xiong, H.Z. Ren, M.H. Li, J.H. Mei, J.F. Wen, C.L. Zheng. Down-regulated miRNA-214 induces a cell cycle G1 arrest in gastric cancer cells by up-regulating the PTEN protein. Pathol. Oncol. Res. 17, 931-937, 2011.

[102] C. H. Xu, M. Xu, L. Tan, H. Yang, J. Permuth-Wey, P.A. Kruk et al. MicroRNA MiR-214 Regulates Ovarian Cancer Cell Stemness by Targeting p53/Nanog. Journal of Biology Chemistry 287(42): 34970-34978, 2012b. Doi: 10.1074/jbc.M112.374611. PMCID: PMC3471722

[103] T. Sharma, R. Hamilton, C.C. Mandal. miR-214: a potential biomarker and therapeutic for different cancers. Future Oncology. 11:349-63, 2015. doi: 10.2217/fon.14.193.

[104] D. X. Peng, M. Luo, L.W. Qiu, Y.L. He, X.F. Wang. Prognostic implications of microRNA-100 and its functional roles in human epithelial ovarian cancer. Oncology Report. 27(4):1238-44, 2012. DOI: 10.3892/or.2012.1625

[105] W. Peng, J. Hu, X.D. Zhu, X. Liu, C.C. Wang, W.H. Li, et al. Overexpression of miR-145 increases the sensitivity of vemurafenib in drug-resistant colo205 cell line. Tumour Biology. 35(4):2983-2988, 2014. doi: 10.1007/s13277-0131383-x.

[106] [107]A. Derfoul, A. H. Juan, M. J. Difilippantonio, N. Palanisamy, T. Ried, V. Sartorelli. Decreased microRNA-214 levels in breast cancer cells coincides with increased cell proliferation, invasion and accumulation of the Polycomb Ezh2 methyltransferase. Carcinogenesis. 32:1607-14, 2011. doi: $10.1093 /$ carcin/bgr184.

[107] [108]. Z. Yang, S. Chen, X. Luan, Y. Li, M. Liu, X. Li, T. Liu, H. Tang. MicroRNA-214 is aberrantly expressed in cervical cancers and inhibits the growth of HeLa cells. IUBMB Life 61, 1075-1082, 2009.

[108] [109]. Q. Rao, H. Zhou, Y. Peng, J. Li, Z. Lin. Aberrant micro-RNA expression in human cervical carcinomas. Medical Oncology. 2011 doi: 10.1007/s12032-011-9830-2

[109] X. Yu, A. Luo, Y. Liu, S. Wang, Y. Li, W. Shi, Z. Liu, X. Qu. MiR-214 increases the sensitivity of breast cancer cells to tamoxifen and fulvestrant through inhibition of autophagy Molecular Cancer. 14: 208, 2015. doi: 10.1186/s12943-0150480-4 PMCID: PMC4678692

[110] H. Schwarzenbach, K. Milde-Langosch, B. Steinbach,V. Muller, K. Pantel. Diagnostic potential of PTEN-targeting miR-214 in the blood of breast cancer patients. Breast Cancer Research and Treatment. 134,933-41, 2012. doi: 10.1007/s10549-012-1988-6.

[111] H. Yang, W. Kong, L. He, J.J. Zhao, J.D. O’Donnell, J. Wang, R.M. Wenham, D. Coppola, P. A. Kruk, S.V. Nicosia, J. Q. Cheng. MicroRNA Expression Profiling in Human Ovarian Cancer: miR-214 Induces Cell Survival and Cisplatin Resistance by Targeting PTEN. Cancer Research, 68:425-433, 2008.
[112] J.L. Bos, H. Rehmann, A. Wittinghofer. GEFs and GAPs: critical elements in the control of small $G$ proteins. Cell. 129(5), 865-877, 2007.

[113] D. Vigil, J. Cherfils, K. L. Rossman, C. J. Der. Ras superfamily GEFs and GAPs: validated and tractable targets for cancer therapy? Nature reviews Cancer. 10(12), 842-857, 2010 .

[114] A. J. G. Lopez, J. A. Lopez. Multistep Model of Cervical Cancer: Participation of miRNAs and Coding Genes. International journal of Molecular Science., 15, 15700-15733, 2014. doi:10.3390/ijms 150915700

[115] M. S. Zaman, D. M. Maher, S. Khan, M. Jaggi, S. C. Chauhan. Current status and implications of microRNAs in ovarian cancer diagnosis and therapy. Journal of Ovarian Research. 5:44, 2012. http://www.ovarianresearch.com/content/5/1/44. Accessed on 12/12/15

[116] S. M. Johnson, H. Grosshans, J. Shingara, M. Byrom, R. Jarvis, A. Cheng, E. Labourier, K. L. Reinert, D. Brown, F.J. Slack . RAS is regulated by the let-7 microRNA family. Cell, 120(5), 635-47, 2005.

[117] L. Wu, J. Fan., J. G. Belasco. MicroRNAs direct rapid dead-enylation of mRNA. Proceedings of National Academy of Science. U S A, 103(11), 4034-9, 2006.

[118] C. Mayr, M. T. Hemann, D. P. Bartel. Disrupting the pairing between let-7 and Hmga2 enhances oncogenic transformation. Science, 315(5818), 1576-1579, 2007.

[119] M. Pal, P. Pal. BRCA1 and miRNAs: An Emerging Therapeutic Target and Intervention Tool in Breast Cancer. Journal of Pharmacology Science and Technology. 3(1), 9-19, 2013.

[120] A. Carta, R. Chetcuti, D. Ayers. An Introspective Update on the Influence of miRNAs in Breast Carcinoma and Neuroblastoma Chemoresistance. Genetics Research International. 2014, Article ID 743050, 13 pages. http://dx.doi.org/10.1155/2014/743050

[121] Z. Liu, J. Liu, M. F. Segura et al.MiR-182 overexpression in tumourigenesis of high-grade serous ovarian carcinoma. Journal of Pathology 228, 204-15, 2012.

[122] X. Wang, C. Tournier. Regulation of cellular functions by the ERK5 signalling pathway, Cellular Signalling, 18(6), 753760,2006

[123] A. A. Wright, B. E. Howitt, A. P. Myers, S. E. Dahlberg, E. Palescandolo, P. V. Hummelen et al. Oncogenic mutations in cervical cancer. Cancer, 2013; Doi: 10.1002/cncr.28288

[124] X. Chen, X. Guo, H. Zhang, Y. Xiang, J. Chen, Y. Yin, X Cai, $\mathrm{K}$. Wang, G. Wang et al. Role of miR-143 targeting KRAS in colorectal tumorigenesis. Oncogene. 28, 1385-1392, 2009.

[125] C. Esau, X. Kang, E. Peralta, E. Hanson, E. G. Marcusson, L. V. Ravichandran. MicroRNA-143 regulates adipocyte differentiation. Journal of Biology Chemistry. 279, 5236152365,2004

[126] H. Wu, Z. Xiao, K. Wang, W. Liu, Q. Hao. MiR-145 is downregulated in human ovarian cancer and modulates cell growth and invasion by targeting p70S6K1 and MUC1. Biochemistry and Biophysic Research Communication, 29; 441(4), 693-700, 2013. doi: 10.1016/j.bbrc.2013.10.053. 
[127] C. Ye, N.X. Sun, Y. Ma, Q. Zhao, Q. Zhang, C. Xu, et al. MicroRNA-145 contributes to enhancing radiosensitivity of cervical cancer cells, 2015. Doi: http://dx.doi.org/10.1016/j.f ebslet.2015.01.037

[128] M. Sachdeva, Y. Y. Mo: MicroRNA-145 suppresses cell invasion andmetastasis by directly targeting mucin 1 . Cancer Research, 70:378-387, 2010.

[129] S. Wang, C. Bian, Z. Yang, Y. Bo, J. Li, L. Zeng, H. Zhou, R. C. Zhao: miR-145 inhibits breast cancer cell growth through RTKN. International Journal of Oncology 34, 1461-1466, 2009.

[130] W. C. Cho, A. S. Chow, J. S. Au. Restoration of tumour suppressor hsa-miR-145 inhibits cancer cell growth in lung adenocarcinoma patients with epidermal growth factor receptor mutation. European Journal of Cancer, 45, 2197$2206,2009$.

[131] J. L. Zhao, D. T. Starczynowski. Role of microRNA-146a in normal and malignant hematopoietic stem cell function. 5(219), 1-6, 2014. doi: 10.3389/fgene.2014.00219

[132] K. Taganov, M. P. Boldin, K. J. Chang, D. Baltimore. NF-kappaB-dependent induction of microRNA miR-146, an inhibitor targeted to signaling proteins of innate immune responses. Proceeding of the National Academy of Science. USA. 103, 12481-12486, 2006.

[133] J. Hou, P.Wang, L. Lin, X. Liu, F. Ma, H. An, Z. Wang, X. Cao. MicroRNA-146a feedback inhibits RIG-I-dependent Type I IFN production in macrophages by targeting TRAF6, IRAK1, and IRAK2. J. Immunol. 183, 2150-2158, 2009.

[134] J. Jurkin, Y. M. Schichl, R. Koeffel, T. Bauer, S. Richter, S. Konradi et al. miR-146a is differentially expressed by myeloid dendritic cell subsets and desensitizes cells to TLR2-dependent activation. J. Immunol. 184, 4955-4965, 2010.

[135] Y. Li, L. Zhao, B. Shi, S. Ma, Z. Xu, Y. Ge, et al. Functions of miR-146a and miR-222 in Tumor-associated Macrophages in Breast Cancer. Scientific Reports, 5(18648), 1-15, 2015. DOI: 10.1038/srep 18648

[136] Liu J, Xie B, Chen S, Jiang F and Meng W. Association study of two inflammation-related polymorphisms with susceptibility to hepatocellular carcinoma: a meta-analysis. BMC Medical Genetics 15: 92, 2014.

[137] S. Vang, H. T. Wu, A. Fischer, D.H. Miller, S. MacLaughlan et al. Identification of Ovarian Cancer Metastatic miRNAs. PLoS ONE 8(3), e58226, 2013. doi:10.1371/journal.pone.00 58226

[138] D. R. Hurst, D. R. Welch. Unraveling the enigmatic complexities of BRMS1-mediated metastasis suppression. FEBS Letter; 585(20), 3185-90, 2011.

[139] J. Shen, C. B. Ambrosone, R. A. DiCioccio et al. A functional polymorphism in the miR-146a gene and age of familial breast/ovarian cancer diagnosis. Carcinogenesis, 29, 1963-6, 2008.

[140] D. Bhaumik, G. K. Scott, S. Schokrpur, C. K. Patil, Campisi J, et al. Expression of microRNA-146 suppresses NF-kappaB activity with reduction of metastatic potential in breast cancer cells. Oncogene 27, 5643-5647, 2008.

[141] C. Scheidereit. ikB kinase complexes: gateways to NFkB activation and transcription. Oncogene. 25, 6685-6705, 2006.

[142] A. Hoffmann, G. Natoli, G. Ghosh. Transcriptional regulation via the NFkB signaling module. Oncogene. 25, 6706-6716, 2006.

[143] M. Karin. How NFkB is activated: the role of the ikB kinase (IKK) complex. Oncogene. 18, 6867-6874, 1999.

[144] A. I. Garcia, M. Buisson, P. Bertrand, R. Rimokh, E. Rouleau, S. Bernard et al. Down-regulation of BRCA1 expression by miR-146a and miR-146b-5p in triple negative sporadic breast cancers. EMBO Molecular Medicine. 3, 279-290, 2011. DOI 10.1002/emmm.201100136

[145] G. Baldassarre, S. Battista, B. Belletti, S. Thakur, F. Pentimalli, F. Trapasso, M. Fedele, G. Pierantoni, C. M. Croce, A. Fusco. Negative regulation of BRCA1 gene expression by HMGA1 proteins accounts for the reduced BRCA1 protein levels in sporadic breast carcinoma. Molecular Cell Biology 23, 2225-2238, 2003.

[146] C. Beger, L. N. Pierce, M. Kruger, E. G. Marcusson, J. M. Robbins, P. Welcsh, P. J. Welch, K. Welte, M. C. King, J. R. Barber et al. Identification of Id4 as a regulator of BRCA1 expression by using a ribozyme-library-based inverse genomics approach. Proceedings National Academy Science. USA 98, 130-135, 2001.

[147] N. C. Turner, J. S. Reis-Filho, A. M. Russell, R. J. Springall, K. Ryder, D. Steele, K. Savage, C. E. Gillett, F. C. Schmitt et al. BRCA1 dysfunction in sporadic basal-like breast cancer. Oncogene 26, 2126-2132, 2007.

[148] R. Sandhu, J. Rein, M. D'Arcy, J. I. Herschkowitz, K. A. Hoadley, M. A. Troester. Overexpression of miR-146a in basal-like breast cancer cells confers enhanced tumorigenic potential in association with altered p53 status. Carcinogenesis. 35(11), 2567-75, 2014. doi: $10.1093 /$ carcin/bgu 175 .

[149] J.E. Cameron, Q. Yin, C. Fewell,, M. Lacey, J. McBride, et al. Epstein-Barr virus latent membrane protein 1 induces cellular MicroRNA miR-146a, a modulator of lymphocyte signaling pathways. Journal of Virology. 82, 1946-1958, 2008.

[150] S. L. Lin, A. Chiang, D. Chang, S. Y. Ying. Loss of mir-146a function in hormone-refractory prostate cancer. RNA 14 , 417-424, 2008.

[151] N. Motsch, T. Pfuhl, J. Mrazek, S. Barth, F. A. Grasser. Epstein-Barr virus-encoded latent membrane protein 1 (LMP1) induces the expression of the cellular MicroRNA miR- 146a. RNA Biology. 4, 131-137, 2007.

[152] D. H. Park, H. S. Jeon, S. Y. Lee, Y. Y. Choi, H. W. Lee S. Yoon et al. MicroRNA-146a inhibits epithelial mesenchymal transition in non-small cell lung cancer by targeting insulin receptor substrate 2. International Journal Oncology. 47(4), 1545-53, 2015. doi: 10.3892/ijo.2015.3111.

[153] H. He, K. Jazdzewski, W. Li, S. Liyanarachchi, R. Nagy et al. The role of microRNA genes in papillary thyroid carcinoma. Proc. Natl. Acad. Sci. USA 102, 19075-19080, 2005.

[154] F. Meng, R. Henson, H. Wehbe-Janek, K. Ghoshal, S. T. Jacob, and T. Patel, "MicroRNA-21 regulates expression of the PTEN tumor suppressor gene in human hepatocellular cancer," Gastroenterology, 133(2): 647-658, 2007.

[155] G. Gabriely, T. Wurdinger, S. Kesari et al. "MicroRNA 21 
promotes glioma invasion by targeting matrix metalloproteinase regulators," Molecular and Cellular Biology, 28(17) 5369-5380, 2008.

[156] K. Wu, L. Li, and S. Li, "Circulating microRNA-21 as a biomarker for the detection of various carcinomas: an updated meta-analysis based on 36 studies," Tumor Biology, 36(3), 1973-1981, 2015.

[157] J. A. Chan, A. M. Krichevsky, K. S. Kosik, "MicroRNA-21 is an antiapoptotic factor in human glioblastoma cells," Cancer Research, 65(14), 6029-6033, 2005.

[158] A. Feber, L. Xi, J. D. Luketich et al., "MicroRNA expression profiles of esophageal cancer," The Journal of Thoracic and Cardiovascular Surgery, 135, (2) 255-260, 2008.

[159] O. Slaby, M. Svoboda, P. Fabian et al., “Altered expression of miR-21, miR-31, miR-143 and miR-145 is related to clinicopathologic features of colorectal cancer," Oncology, 72(5-6), 397-402, 2008.

[160] P. M. Haverty, J. Fridlyand, L. Li, G. Getz, R. Beroukhim, S. Lohr, et al. High-resolution genomic and expression analyses of copy number alterations in breast tumors. Genes Chromosomes Cancer, 47, 530-42, 2008.

[161] T. Hayashi, N. Koyama, Y. Azuma, M. Kashimata. Mesenchymal miR-21 regulates branching morphogenesis in murine submandibular gland in vitro. Developmental Biology, 352, 299-307, 2011.

[162] K. E. Resnick, H. Alder, J. P. Hagan, D. L. Richardson, C. M. Croce, D. E. Cohn. The detection of differentially expressed microRNAs from the serum of ovarian cancer patients using a novel real-time PCR platform. Gynecologic Oncology 112, 55-59, 2009. doi:10.1016/j.ygyno.2008.08.036

[163] A. S. Gardiner, W. C. McBee, Jr. et al., "MicroRNA analysis in human papillomavirus (HPV)-associated cervical neoplasia and cancer," Journal Carcinogene Mutagene, 5(S1), article A55, 2011.

[164] M. L. Si, S. Zhu, H. Wu et al. miR-21-mediated tumor growth Suppression of tumor growth by anti-miR-21. Oncogene, 26 , 2799-803, 2007.

[165] S. Zhu, H. Wu, F. Wu, D. Nie, S. Sheng, Y. Y. Mo. MicroRNA-21 targets tumor suppressor genes in invasion and metastasis. Cell Research, 18(3), 350-9, 2008.

[166] L. Huang, J. H. Luo, Q. Q. Cai, Q. H. Pan, H. Zeng, G.H. Guo, W. Dong et al. MicroRNA-125b suppresses the development of bladder cancer by targeting E2F3. International Journal Cancer, 128, 1758-1769, 2011.

[167] D. Kalniete, M. Nakazawa-Miklasevica, I. Strumfa, A. Abolins, A. Irmejs, G. Trofimovics. MicroRNA Expression in Different Sybtypes of Breast Cancer. Acta Chirurgica Latviensis. 2013 (13): 7-12. Doi: 10.2478/chilat-2013-0002

[168] I Faraoni, S Laterza, D Ardiri, C Ciardi, F Fazi and F Lo-Coco. MiR-424 and miR-155 deregulated expression in cytogenetically normal acute myeloid leukaemia: correlation with NPM1 and FLT3 mutation status. Journal of Hematology \& Oncology, 5, 26, 2012. DOI: $10.1186 / 1756-8722-5-26$

[169] A. Esquela-Kerscher, F.J. Slack, Oncomirs - microRNAs with a role in cancer, Nat. Rev. Cancer 6 (2006) 259-269.
[170] Neilsen PM, Noll JE, Suetani RJ, Schulz RB, Al-Ejeh F, Evdokiou A, et al. Mutant p53 uses p63 as a molecular chaperone to alter gene expression and induce a pro-invasive secretome. Oncotarget, 2(12), 1203-17, 2011.

[171] D. Ovcharenko, K. Kelnar, C. Johnson, N. Leng, D. Brown, Genome-scale microRNA and small interfering RNA screens identify small RNA modulators of TRAIL induced apoptosis pathway, Cancer Research. 67 10782-10788, 2007.

[172] M. Gironella, M. Seux, M.J. Xie, C. Cano, R. Tomasini, J. Gommeaux, S. et al. Tumor protein 53-induced nuclear protein 1 expression is repressed by miR-155, and its restoration inhibits pancreatic tumor development, Proceedings National Academy. Science. U. S. A. 104, 161716170, 2007.

[173] D. D. Taylor, C. Gercel-Taylor. MicroRNA signatures of tumor-derived exosomes as diagnostic biomarkers of ovarian cancer. Gynecologic Oncology 110, 13-21, 2008.

[174] G. M. Schratt, F. Tuebing, E. A. Nigh, C. G. Kane,M. E. Sabatini, M. Kiebler et al. A brain-specific microRNA regulates dendritic spine development. Nature, 439, 283-8, 2006.

[175] I. K. Guttilla, B. A. White. Coordinate regulation of FOXO1 by miR-27a, miR-96, and miR-182 in breast cancer cells. Journal of Biolology Chemistry, 284, 23204-16, 2009.

[176] A. K. Nagaraja, C. J. Creighton, Z. Yu et al. A link between mir-100 and FRAP1/mTOR in clear cell ovarian cancer.Mol Endocrinology 24, 447-63, 2010.

[177] C. H. Chiang, M. F. Hou, W. C. Hung.Up-regulation of miR-182 by beta-catenin in breast cancer increases tumorigenicity and invasiveness by targeting the matrixmetalloproteinase inhibitor RECK. Biochim Biophys Acta 1830, 3067-76, 2013.

[178] S. S. Myatt, E. W. Lam. The emerging roles of forkhead box (Fox) proteins in cancer. Nature Review Cancer, 7, 847-59, 2007.

[179] R. Lei, J. Tang, X. Zhuang et al. Suppression of MIM by microRNA-182 activates RhoA and promotes breast cancer metastasis. Oncogene, 33, 1287-96, 2014.

[180] P. Moskwa, F. M. Buffa, Y. Pan et al. miR-182-mediated downregulation of BRCA1 impacts DNA repair and sensitivity to PARP inhibitors. Mol ecular Cell 41, 210-20, 2011.

[181] Q. Wei, R. Lei, G. Hu. Roles of miR-182 in sensory organ development and cancer. Thoracic Cancer 6(2-9), 2015. doi: 10.1111/1759-7714.12164

[182] L. Zhang, S. Volinia, T. Bonome, G.A. Calin, J. Greshock, N. Yang et al. Genomic and epigenetic alterations deregulate microRNA expression inhuman epithelial ovarian cancer. Proceedings of the National Academy Science. U.S.A. 105, 7004-7009, 2008. doi:10.1073/pnas.0801615105

[183] A. Chao, C.Y. Lin, Y.S. Lee, C.L. Tsai, P. C. Wei, S. Hsueh, T. I. Wu, C. N. Tsai, C. J. Wang, A. S. Chao, T. H. Wang, C. H. Lai. Regulation of ovarian cancer progression by microRNA-187 through targeting Disabled homolog-2. Oncogene. 31, 764-75, 2012.

[184] S. K. Wyman, R. K. Parkin, P. S. Mitchell, B. R. Fritz, K. O'Briant, A. K. Godwin, N. Urban, C. W. Drescher, B. S. 
Knudsen, M. Tewari. Repertoire of microRNAs in epithelial ovarian cancer as determined by next generation sequencing of small RNA cDNA libraries. PLoS One 2009, 4:e5311.

[185] Y. Saito, G. Liang, G. Egger, J. M. Friedman, J. C. Chuang, G. A. Coetzee. Specific activation of microRNA-127 with down-regulation of the proto-oncogene BCL6 by chromatin-modifying drugs in human cancer cells. Cancer Cell, 9, 435-443, 2006.

[186] M. K. Kayani, M. A. Kayani, F. A. Malik, R. Faryal. Role of miRNAs in Breast Cancer. Asian Pacific Journal of Cancer Prevention, 12, 3175-3180, 2011.

[187] Y. Shimono, M. Zabala, R.W. Cho, N. Lobo, P. Dalerba, D. Qian, M. Diehn. et al. Downregulation of miRNA-200c links breast cancer stem cells with normal stem cells. Cell, 138, 592-603, 2009.

[188] U. Wellner, J. Schubert, U. C. Burk, O. Schmalhofer, F. Zhu, J. Schüler, M. P. Stemmler. The EMT-activator ZEB1 promotes tumorigenicity by repressing stemness-inhibiting microRNAs. Nat. Cell Biol., 11, 1487-1495, 2009.

[189] C.W.S. Kan, M. A. Hahn, G.B. Gard, J. Maidens, J.Y. Huh, D.J. Marsh, V.M. Howell. Elevated levels of circulating microRNA-200 family members correlate with serous epithelial ovarian cancer. BMC Cancer, 12, 627, 2012. DOI: $10.1186 / 1471-2407-12-627$

[190] A. Bendoraite, E. C. Knouf, K. S. Garg, R. K. Parkin, E. M. Kroh, K. C. O'Briant et al. Regulation of miR-200 family microRNAs and ZEB transcription factors in ovarian cancer: evidence supporting a mesothelial-to-epithelial translation. Gynecology Oncology, 116, 117 - 125, 2010.

[191] Mateescu B, Batista L, Cardon M, Gruosso T, de Feraudy Y, Mariani O, Nicolas A, Meyniel JP, Cottu P, Sastre-Garau X \& Mechta-Grigoriou F. miR-141 and miR-200a act on ovarian tumorigenesis by controlling oxidative stress response. Nat Med 171627 - 1635, 2011.

[192] J. Snowdon, X. Zhang, T. Childs, V.A. Tron and H. Feilotter. The microRNAs-200 family is upregulated in endometrial carcinoma. PLoS One 6 e22828, 2011.

[193] J.W. Lee, Y. A. Park, J. J. Choi, Y. Y. Lee, C. J. Kim, C. Choi, et al. The expression of the miRNA-200 family in endometrial endometrioid carcinoma. Gynecol 885 Oncol $12056-62,2011$.

[194] Y. A. Park, J.W. Lee JW, Choi JJ, Jeon HK, Cho Y, Choi C, Kim TJ, Lee NW, Kim BG \& Bae DS. The interactions between MicroRNA-200c and BRD7 in endometrial carcinoma. Gynecology and Oncology, 124125 - 133, 2012.

[195] J. G. Zhang, J. J. Wang, F. Zhao, Q. Liu, K. Jiang, G. H. Yang. MicroRNA-21 (miR-21) represses tumor suppressor PTEN and promotes growth and invasion in non-small cell lung cancer (NSCLC). International Journal Clinical Chemistry, 411, 846-852, 2010.

[196] B. Muralidhar, D. Winder, M. Murray, R. Palmer, N. Barbosa-Morais, H. Saini, I. Roberts, M. Pett, N. Coleman. Functional evidence that Drosha overexpression in cervical squamous cell carcinoma affects cell phenotype and microRNA profiles. Journal Pathology. 224, 496-507, 2011.

[197] J. T. Mendell. miRiad roles for the miR-17-92 cluster in development and disease. Cell, 133(2), 217-22, 2008.
[198] K. B. Zhai, B. Hotary, B. Nan, F. X. Bosch, N. Munoz, Stephen J. Weiss, K. R. Cho. Expression of membrane type 1 matrix metalloproteinase is associated with cervical carcinoma progression and invasion," Cancer Research, 65(15), 6543-6550, 2005.

[199] T. Hagemann, T. Bozanovic, S. Hooper et al., "Molecular profiling of cervical cancer progression," British Journal of Cancer, 96(2), 321-328, 2007.

[200] Y. F. Wong, T. H. Cheung, G. S. W. Tsao et al. Genomewide gene expression profiling of cervical cancer in Hong. International journal of Cancer, 118(10), 2461-2469, 2005.

[201] Q. Yao, H. Xu, Q. Q. Zhang, H. Zhou, L.H. Qu. "MicroRNA-21 promotes cell proliferation and down-regulates the expression of programmed cell death 4 (PDCD4) in HeLa cervical carcinoma cells. Biochemical and Biophysical Research Communications, 388(3), 539-542, 2009.

[202] T. Yao, Z. Lin. MiR-21 is involved in cervical squamous cell tumorigenesis and regulates CCL20," Biochimica et Biophysica Acta, 1822(2), 248-260, 2012.

[203] L. B. Frankel, N. R. Christoffersen, A. Jacobsen, M. Lindow, A. Krogh, A. H. Lund. Programmed cell death 4 (PDCD4) is an important functional target of the microRNA miR-21 in breast cancer cells. Journal of Biology Chemistry, 283(2), 1026-33, 2008

[204] L. Qi, J. Bart, L. P. Tan, I. Platteel, T. Sluis, S, Huitema, G. Harms, L. Fu, H. Hollema, A. Berg. Expression of miR-21 and its targets (PTEN, PDCD4, TM1) in flat epithelial atypia of the breast in relation to ductal carcinoma in situ and invasive carcinoma. Cancer BMC, 9, 163, 2009.

[205] S. Zhu, M. L. Si, H. Wu, Y. Y. Mo. MicroRNA-21 targets the tumor suppressor gene tropomyosin 1 (TPM1). Journal of Biology and Chemistry. 282(19), 14328-36, 2007.

[206] S. Zhu, H. Wu, F. Wu, D. Nie, S. Sheng, Y. Y. Mo. MicroRNA-21 targets tumor suppressor genes in invasion and metastasis. Cell Research 18(3), 350-9, 2008. Doi: $10.1038 /$ cr.2008.24

[207] M. L. Si, S.Zhu, H. Wu, Z. Lu, F. Wu, Y.Y. Mo. miR-21-mediated tumor growth. Oncogene 26, 2799-2803, 2007.

[208] W. Qin, Q. Ren, T. Liu, Y. Huang, J. Wang. MicroRNA-155 is a novel suppressor of ovarian cancer-initiating cells that targets CLDN1. FEBS Letters 587, 1434-1439, 2013.

[209] W. Kong, H. Yang, L. He, J.J. Zhao, D. Coppola, W.S Dalton, J. Q. Cheng. MicroRNA-155 is regulated by the transforming growth factor beta/Smad pathway and contributes to epithelial cell plasticity by targeting RhoA. Molecular Cell Biology, 28(22), 6773-84, 2008.

[210] J. Sun, J. Ji, G. Huo, Q. Song, X. Zhang. MiR-182 induces cervical cancer cell apoptosis through inhibiting the expression of DNMT3a. International Journal of Clinical Experiment and Pathology. 8(5), 4755-4763, 2015.

[211] Y. Guo, Y. Liao, C. Jia, J. Ren, J. Wang, T. Li. MicroRNA-182 Promotes Tumor Cell Growth by Targeting Transcription Elongation Factor A-like 7 in Endometrial Carcinoma. Cell Physiology and Biochemistry, 32, 581-590, 2013. DOI: $10.1159 / 000354462$ 
[212] P. Gasparini, F. Lovat, M. Fassan, L. Casadei, L. Cascione, N. K. Jacob et al. Protective role of miR-155 in breast cancer through RAD51 targeting impairs homologous recombination after irradiation. Proceedings of the National Academy of Science U S A, 111, 4536-41, 2014.

[213] D. M. Dykxhoorn, Y. Wu, H. Xie, et al. miR-200 enhances mouse breast cancer cell colonization to form distant metastases. PLoS One, 4:e7181, 2009.

[214] H. Suzuki, R. Maruyama, E. Yamamoto, M. Kai. DNA methylation and microRNA dysregulation in cancer. Molecular oncology 6, 567-578, 2012.

[215] D. Schottenfeld, J. Beebe-Dimmer. Chronic inflammation: a common and important factor in the pathogenesis of neoplasia. CA Cancer Journal of Clinicians, 56, 69-83, 2006.

[216] P. A. Gregory, A. G. Bert, E. L. Paterson, S. C. Barry, A. Tsykin. The miR-200 family and miR-205 regulate epithelial to mesenchymal transition by targeting ZEB1 and SIP1. Nature Cell Biology 10(5), 593-601, 2008.

[217] S.P. Hussain, L.J. Hofseth, C.C. Harris. Radical causes of cancer. Nature Review Cancer. 3, 276-85, 2003.

[218] D. Wang, J.R. Mann, R.N. DuBois. The role of prostaglandins and other eicosanoids in the gastrointestinal tract. Gastroenterology. 128, 1445-61, 2005.

[219] Y. Habraken, J. Piette. NF-kappaB activation by double-strand breaks. Biochemistry and Pharmacology. 72, 1132-41, 2006.

[220] A. Trafton. Study details a link between inflammation and cancer: Timing of inflammation determines whether potentially cancerous mutations may arise. Massachusetts Institute of Technology, 2015. Available from: http://news.mit.edu/2015/link-between-inflammation-and-ca ncer-0115. Accessed on 14/03/2016

[221] J. Stanczyk, D.M. Pedrioli, F. Brentano, O. Sanchez-Pernaute, C. Kolling, R.E. Gay, M. Detmar, S. Gay, D. Kyburz, Altered expression of microRNA in synovial fibroblasts and synovial tissue in rheumatoid arthritis, Arthritis and Rheumatology. 58, 2008.

[222] E. Sonkoly, A. Pivarcsi. microRNAs in Inflammation. International Review in Immunology 28, 535-561, 2009.

[223] K. Yamasaki, T. Nakasa, S. Miyaki, M. Ishikawa, M. Deie, N. Adachi, Y. Yasunaga, H. Asahara, M. Ochi. Expression of MicroRNA-146a in osteoarthritis cartilage. Arthritis and Rheumatology 60, 1035-41, 2009.

[224] T. Nakasa, S. Miyaki, A. Okubo, M. Hashimoto, K. Nishida, M. Ochi, H. Asahara. Expression of microRNA-146 in rheumatoid arthritis synovial tissue. Arthritis and Rheumatology. 58, 1284-92, 2008.

[225] K. M. Pauley, M. Satoh, A. L. Chan, M. R. Bubb, W. H. Reeves, E. K. Chan. Upregulated miR-146a expression in peripheral blood mononuclear cells from rheumatoid arthritis patients. Arthritis Research and Therapy, 10, R101, 2008

[226] M.S. Wicha, S. Liu, G. Dontu. Cancer stem cells: an old idea-a paradigm shift. Cancer Research 66(4), 1883-1890; Discussion 1895-1896, 2006

[227] M. Al-Hajj, M.W. Becker, M. Wicha, I. Weissman, M.F. Clarke. Therapeutic implications of cancer stem cells. Current
Opinion in Genetics Development, 14(1), 43-47, 2004.

[228] S. Sell. Stem cell origin of cancer and differentiation therapy. Crit Rev Oncol Hematol 51(1), 1-28, 2004

[229] J. Houghton, A. Morozov, I. Smirnova, T.C. Wang. Stem cells and cancer. Semin Cancer Biol 17(3), 191-203, 2007.

[230] X. Li, M.T. Lewis, J. Huang, C. Gutierrez, C.K. Osborne, M.F. Wu, S.G. Hilsenbeck, A. Pavlick, X. Zhang, G.C. Chamness, et al. Intrinsic resistance of tumorigenic breast cancer cells to chemotherapy. J National Cancer Institute, 100(9), 672-679, 2008.

[231] L.L. Campbell, K. Polyak, Breast tumor heterogeneity: cancer stem cells or clonal evolution? Cell Cycle. 6(19), $2332-8,2007$

[232] C.Y. Park, D. Tseng, I.L. Weissman. Cancer stem celldirected therapies: recent data from the laboratory and clinic. Molecular Therapy. 17(2), 219 - 30, 2009

[233] J.E. Visvader, G.J. Lindeman. Cancer stem cells in solid tumours: accumulating evidence and unresolved questions. Nature Review Cancer, 8(10), 755 - 68, 2008

[234] M. Al-Hajj, M.S. Wicha, A. Benito-Hernandez, S.J. Morrison, M.F. Clarke. Prospective identification of tumorigenic breast cancer cells. Proc Natl Acad Sci USA 100(7), 3983-3988, 2003.

[235] S.K. Singh, I.D. Clarke, M. Terasaki, V.E. Bonn, C. Hawkins, J. Squire, P.B. Dirks. Identification of a cancer stem cell in human brain tumors. Cancer Research, 63(18), 5821-5828, 2003

[236] R. Galli, E. Binda, U. Orfanelli, B. Cipelletti, A. Gritti, S. De Vitis, R. Fiocco, C. Foroni, F. Dimeco, A. Vescovi. Isolation and characterization of tumorigenic, stem-like neural precursors from human glioblastoma. Cancer Research, 64(19), 7011-7021, 2004.

[237] C.P. Gibbs, V.G. Kukekov, J.D. Reith, O. Tchigrinova, O.N. Suslov, E.W. Scott, S.C. Ghivizzani, T.N. Ignatova, D.A. Steindler. Stem-like cells in bone sarcomas: implications for tumorigenesis. Neoplasia 7(11), 967-976, 2005.

[238] C.F. Kim, E.L. Jackson, A.E. Woolfenden, S. Lawrence, I. Babar, S. Vogel, D. Crowley, R.T. Bronson, T. Jacks. Identification of bronchioalveolar stem cells in normal lung and lung cancer. Cell 121(6), 823-835, 2005.

[239] D. Fang, T.K. Nguyen, K. Leishear, R. Finko, A.N. Kulp, S. Hotz, P.A. Van Belle, X. Xu, D.E. Elder, M. Herlyn. A tumorigenic subpopulation with stem cell properties in melanomas. Cancer Research, 65(20), 9328-9337, 2005

[240] A.T. Collins, N.J. Maitland. Prostate cancer stem cells. European Journal of Cancer, 42(9), 1213-1218, 2006.

[241] C.A. O'Brien, A. Pollett, S. Gallinge, J.E. Dick. A human colon cancer cell capable of initiating tumour growth in immunodeficient mice. Nature 445(7123), 106-110, 2007.

[242] L. Ricci-Vitiani, D.G. Lombardi, E. Pilozzi, M. Biffoni, M. Todaro, C. Peschle, R. De Maria. Identification and expansion of human colon-cancer- initiating cells. Nature 445(7123), 111-115, 2007

[243] C. Li, D.G. Heidt, P. Dalerba, C.F. Burant, L. Zhang, V. Adsay, M. Wicha, M.F. Clarke, D.M. Simeone. Identification of pancreatic cancer stem cells. Cancer Research 67(3), 
$1030-1037,2007$

[244] M.E. Prince, R. Sivanandan, A. Kaczorowski, G.T. Wolf, M.J. Kaplan, P. Dalerba, I.L. Weissman, M.F. Clarke, L.E. Ailles. Identification of a subpopulation of cells with cancer stem cell properties in head and neck squamous cell carcinoma. Proceedings of the National Academy of Science USA, 104(3), 973-978, 2007.

[245] M. Shipitsin, L.L. Campbell, P. Argani P, et al: Molecular definition of breast tumor heterogeneity. Cancer Cell, 11, 259-273, 2007.

[246] S.M. Suraneni, M.D. Badeaux. Tumor-Initiating Cells, Cancer Metastasis and Therapeutic Implications, 2013. Available at: www.http//:Madame Curie Bioscience Database - NCBI Bookshelf.html. Accessed 09/14/2016.

[247] T. Reya, S.J. Morrison, M.F. Clarke, I.L. Weissman. Stem cells, cancer, and cancer stem cells. Nature 414(6859), 105111,2001

[248] G. Dontu, M. Al-Hajj, W.M. W.M. Abdallah, M.F. Clarke, M.S. Wicha. Stem cells in normal breast development and breast cancer. Cell Prolif 36(suppl 1), 59-72, 2003.

[249] P.A. Beachy, S.S. Karhadkar, D.M. Berman. Tissue repair and stem cell renewal in carcinogenesis. Nature 432, 324-331, 2004.

[250] E.K.S. Bernstein, M.A. Carmell, E.P. Murchison, H. Alcorn, M.Z. Li, A.A. Mills, S.J. Elledge, K.V. Anderson, G.J. Hannon. Dicer is essential for mouse development. Nat Genet 35: 215-217, 2003.

[251] C. Kanellopoulou, S.A. Muljo, A.L. Kung, et al. Dicer-deficient mouse embryonic stem cells are defective in differentiation and centromeric silencing. Genes Dev 19: 489-501, 2005.

[252] M.R. Suh, Y. Lee, J.Y. Kim, et al. Human embryonic stem cells express a unique set of microRNAs. Developmental Biology, 270, 488-498, 2004.
[253] C.M. Croce, G.A. Calin. miRNAs, cancer, and stem cell division. Cell 122: 6-7, 2005.

[254] L. He, J.M. Thomson, M.T. Hemann, E. Hernando-Monge, D. $\mathrm{Mu}, \mathrm{S}$. Powers, C. Cordon-Cardo, S.W. Lowe, G.J. Hannon, S.M. Hammond. A micro-RNA polycistron as a potential human oncogene. Nature 435(7043), 828-833, 2005.

[255] J. Lu, G. Getz, E.A. Miska, E. Alvarez-Saavedra, J. Lamb, D. Peck, A. Sweet-Cordero, B.L. Ebert, R.H. Mak, A.A. Ferrando, et al. MicroRNA expression profiles classify human cancers. Nature 435(7043), 834-838, 2005.

[256] C.Z. Chen. MicroRNAs as oncogenes and tumor suppressors. New England Journal of Medicine 353(17), 1768-1771, 2005.

[257] G.A. Calin, C.M. Croce. MicroRNA signatures in human cancers. Nat Rev Cancer 6(11), 857-866, 2006.

[258] F. Yu. et al. let-7 regulates self renewal and tumorigenicity of breast cancer cells. Cell 131, 1109-1123, 2007.

[259] I. Ibarra, Y. Erlich, S.K. Muthuswamy, R. Sachidanandam, G.J. Hannon. A role for microRNAs in maintenance of mouse mammary epithelial progenitor cells. Genes Dev 21: 3238-3243, 2007.

[260] J.C. Wang. Good cells gone bad: the cellular origins of cancer. Trends in Molecular Medicine.16:145-51, 2010. Available from: http://dx.doi.org/10.1016/j.molmed.2010.01.001

[261] J.W. Pek, A.K. Lim, T. Kai. Drosophila maelstrom ensures proper germline stem cell lineage differentiation by repressing microRNA-7. Developments in Cell 17, 417-424, 2009.

[262] S.K. Singh, M.N. Kagalwala, J. Parker-Thornburg, H. Adams, S. Majumder. REST maintains self-renewal and pluripotency of embryonic stem cells. Nature, 453, 223-227, 2008.

[263] L. Shi, J. Zhang, T. Pan, et al. MiR-125b is critical for the suppression of human U251 glioma stem cell proliferation. Brain Research, 1312, 120-126, 2010 